\title{
Basalt-Radionuclide Distribution Coefficient Determinations FY-1979 Annual Report
}

L. L. Ames

J. E. McGarrah

September 1980

Prepared for Rockwell Hanford Operations

Under Contract DE-AC06-76-RLO 1830

Pacific Northwest Laboratory

Operated for the U.S. Department of Energy

by Battelle Memorial Institute 


\title{
NOTICE
}

This report was prepared as an account of work sponsored by the United States Government. Neither the United States nor the Department of Energy, nor any of their employees, nor any of their contractors, subcontractors, or their employees, makes any warranty, express or implied, or assumes any legal liability or responsibility for the accuracy, complereness or usefulness of any information. apparatus, product or process disclosed, or represents that its use would not infringe privately owned rights.

The views. opinions and conclusions contained in this report are those of the contractor and do not necessarily represent those of the United States Government or the United States Department of Energy.

\author{
PACIFIC NORTHWEST LABORATORY \\ operated by \\ BATTELLE \\ for the \\ UNITED STATES DEPARTMENT OF ENERGY \\ Under Contract DE-AC06-76RLO 1830
}
Printed in the United States of America
Available from
National Technical Information Service
United States Department of Commerce 5285 Port Royal Rosd
Springfield. Virginia 22151

Price: Printed Copys

$\therefore$ Microfiche $\$ 33,00$

NTIS

-Pages Selling Price

\begin{tabular}{|c|c|}
\hline 001.025 & 54.00 \\
\hline $026-050$ & 54.50 \\
\hline $051-075$ & $\$ 5.25$ \\
\hline $076-100$ & $\$ 6.00$ \\
\hline $101-125$ & 56,50 \\
\hline $126-150$ & 57.25 \\
\hline $151 \cdot 175$ & sa.00 \\
\hline $176-200$ & $\$ 9.00$ \\
\hline $201 \cdot 225$ & 59.25 \\
\hline $226-250$ & $\$ 9.50$ \\
\hline $251-275$ & 510.75 \\
\hline $256-300$ & $\$ 11.00$ \\
\hline
\end{tabular}


PNL-3146

UC -70

\section{9}

BASALT-RADIONUCLIDE DISTRIBUTION

COEFF ICIENT DETERMINATIONS

FY-1979 ANNUAL REPORT

L. L. Ames

J. E. McGarrah

September 1980

Prepared for Rockwe 11 Hanford Operations Under Contract DE-AC06-76-RLO 1830

Pacific Northwest Laboratory Richland, Washington 99352 

Experimental radionuclide distribution coefficients (Kd') were determined for Pomona, Flow E, Umtanum basalts, and secondary mineralization associated with the Pomona basalt at $23^{\circ}, 60^{\circ}$ and $150^{\circ} \mathrm{C}$. Radionuclides used were ${ }^{75} \mathrm{Se}$,

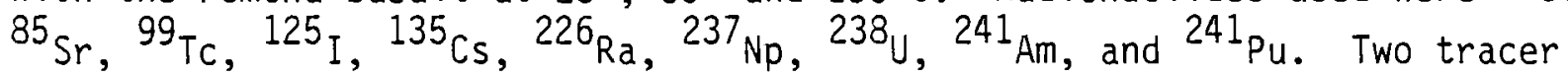
concentration levels and two solid weight to solution volume ratios were run in triplicate. Solution oxygen contents were controlled by the basalt/ groundwater system ( $E \mathrm{~h}=600$ to $700 \mathrm{mv})$, and were high $(8.2$ to $8.4 \mathrm{mg} / 1$ ) at $23^{\circ} \mathrm{C}$. Oxygen contents and $\mathrm{pH}$ changed little in contact with basalt.

The effects of temperature changes on radionuclide $K d^{\prime}$ results varied depending upon the radionuclide involved, solution-solid reactions, and the relationship of the radionuclide to these reactions. For example, cesium $\mathrm{Kd}^{\prime}$ values decreased from $3100 \mathrm{ml} / \mathrm{g}$ for Umtanum basalt at $23^{\circ} \mathrm{C}$ to $120 \mathrm{ml} / \mathrm{g}$ at $150^{\circ} \mathrm{C}$. At the same time, strontium $\mathrm{Kd}$ ' values increased for Umtanum basalt from $105 \mathrm{ml} / \mathrm{g}$ at $23^{\circ} \mathrm{C}$ to complete removal at $150^{\circ} \mathrm{C}$ and 40 days.

Radionuclide adsorption coefficient measurements at higher temperatures and pressures were made in addition to the $23^{\circ} \mathrm{C}$, solution-solid contact timeconditional $\mathrm{Kd}\left(\mathrm{Kd} \mathrm{d}^{\prime}\right)$ measurements. These included $\mathrm{Kd}$ ' measurements with Umtanum basalt, Pomona basalt, Flow E basalt and secondary mineralization and radioisotopes of americium, cesium, iodine, neptunium, plutonium, radium, selenium, strontium, technetium and uranium. The additional temperatures involved were $60^{\circ} \mathrm{C}, 150^{\circ} \mathrm{C}$, and $300^{\circ} \mathrm{C}$. At $150^{\circ} \mathrm{C}$, argon pressures of $6.9,13.8$, 20.7 , and $27.6 \mathrm{MPa}$ will be used to ascertain the effects of pressure changes on $\mathrm{Kd}$ ' values. So far only the $6.9 \mathrm{MPa}$ argon pressure has been investigated. The upper temperature of $250^{\circ} \mathrm{C}$ is where thermal breakdown of dioctahedral smectites (secondary mineralization) begins (Eberl et al. 1978). The present predicted maximum temperature is $300^{\circ} \mathrm{C}$ for the thermal regime of repository mined in basalt. Hence, the basalts (along with reconstitution to new mineral phases) on radionuclide $\mathrm{Kd}^{\prime}$ values will be determined at $300^{\circ} \mathrm{C}$. 



\section{CONTENTS}

SUMMARY

FIGURES

TABLES

INTRODUCTION

CONCLUSIONS

DISTRIBUTION COEFFICIENT PRECISION IMPROVEMENT

EXPERIMENTAL IMPROVEMENT .

REPLICATION

EXPERIMENTAL RESULTS

$23^{\circ} \mathrm{C}$ STATIC Kd EXPERIMENTS

$60^{\circ} \mathrm{C}$ STATIC Kd EXPERIMENTS

$150^{\circ} \mathrm{C}$ STATIC Kd EXPERIMENTS

REFERENCES

APPENDIX A - CHARACTERIZATION OF FLOW E AND POMONA BASALTS

A.1

APPENDIX B - CHARACTERIZATION OF SECONDARY MINERALIZATION . .

B.1

APPENDIX C - SURFACE AREA MEASUREMENT WITH ETHYLENE GLYCOL . •

C.1

APPENDIX D - OUTLINE OF $150^{\circ} \mathrm{C}$ EXPERIMENTS . . . . . . . . . . 0.1

APPENDIX E - OUTLINE OF $300^{\circ} \mathrm{C}$ EXPERIMENTS . . . . . . . . . E.I

APPENDIX $F$ - EFFECTS OF WEATHERING ON SURFACES OF UMTANUM BASALT .

F.1 



\section{FIGURES}

1 Apparent Cesium Kd' Variation of $<2 \mu \mathrm{m}$ Nontronite at Several Solution to Solid Ratios and 30 Days Equilibrium

Time With Shaking . $. \quad . \quad . \quad . \quad . \quad$.. .

2 Apparent Cesium Kd' Variation for Umtanum Basalt at Several Solution to Solid Ratios and 30 Days Equilibrium Time With Shaking

3 Cesium Kd' Values Versus Equilibration Time at $23^{\circ} \mathrm{C}$ for Umtanum Basalt and Synthetic Groundwater. . . . .

4 Strontium $\mathrm{Kd}$ ' Values Versus Equilibration Time at $23^{\circ} \mathrm{C}$

for Umtanum Basalt and Synthetic Groundwater.

5 Cesium Kd' Value Versus Contact Time in Days for Umtanum Basalt at $150^{\circ} \mathrm{C}$ and $6.9 \mathrm{MPa} \mathrm{Ar}, 1 \mathrm{~g}$ Basalt/10 $\mathrm{ml}$ of Synthetic Groundwater . . . . . . . . . 26

B.1 X-Ray Diffraction Patterns of Treated and Untreated Fracture Mineralization . . . . . . . . . B.3

F.1 Weathered Basalt Section. . . . . . . . . F.2

F.2 Hydrothermally Treated Basalt Sections . . • . . . . F.2

F.3 Unweathered Basalt Section (500X) . . . . . . . F.3

F.4 Weathered Basalt Section (500X) . . . . . . . F.3

F.5 Unweathered Basalt Section (2000X) . . . . . . . F.4

F.6 Weathered Basalt Section (2000X) . . . . . . . F.4 


\section{TABLES}

1 Less than Two Micrometer, Freeze-Dried Nontronite Cesium 30-Day Kd' Variations With Solution to Solid Ratio

and Equilibrium Solution Treatment . . . . . . . . . 8

2 Umtanum Basalt $23^{\circ} \mathrm{C}$ Cesium Kd' Variation With

Solution Volume to Solid Weight Ratio . . . . . . . . . 99

3 ICP Trace Element Analysis of the Original and 108-Day

Equilibrating Solution With Umtanum Basalt . . . . . . . 10

4 Kd's Values for Umtanum Basalt at $23^{\circ} \mathrm{C}$ Under

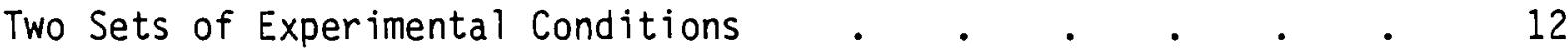

5 Synthetic Groundwater Formulation GR-1 . . . . . . . . 16

6 The $23^{\circ} \mathrm{C}, 1 \mathrm{~g} / 10 \mathrm{ml}$ Solution Kd' Values for

Basalt and Synthetic Groundwater GR-1 . . . . . . .

7 The $23^{\circ} \mathrm{C}, 1 \mathrm{~g} / 80 \mathrm{ml}$ Solution Kd' Values for

Basalt and Synthetic Groundwater GR-1 . . . . . . . . . 18

8 The $23^{\circ} \mathrm{C} \mathrm{Kd'} \mathrm{Values} \mathrm{for} \mathrm{Secondary} \mathrm{Mineralization} \mathrm{and}$

Synthetic Groundwater GR-1 . $\quad$ • $\quad$ • . . . . . .

9 The $23^{\circ} \mathrm{C}, 1 \mathrm{~g}$ Basalt/10 ml Synthetic Groundwater Solution

$\mathrm{pH}$ Values at 83 Days of Contact Time . . . . . . .

10 Dissolved 0xygen in the Solution Contacting 0.30 to $0.85-\mathrm{mm}$

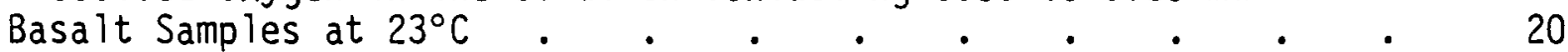

11 The $60^{\circ} \mathrm{C} \mathrm{Kd'} \mathrm{Values} \mathrm{for} 0.30$ to $0.85-\mathrm{mm}$ Basalts and

Synthetic Groundwater GR-1 at $1 \mathrm{~g}$ Basalt/10 ml Solution . . 22

12 The $60^{\circ} \mathrm{C} \mathrm{Kd'} \mathrm{Values} \mathrm{for} \mathrm{Basalts} \mathrm{and} \mathrm{Synthetic}$

Groundwater GR-1 at $1 \mathrm{~g}$ Basalt/80 ml Solution

13 The $60^{\circ} \mathrm{C} \mathrm{Kd'} \mathrm{Values} \mathrm{for} \mathrm{Secondary} \mathrm{Mineralization} \mathrm{and}$

Synthetic Groundwater GR-1

14 Measured Blank Solution $\mathrm{Kd}^{\prime}$ Values at $150^{\circ} \mathrm{C}$ and $6.9 \mathrm{MPa} \mathrm{Ar}$ With and Without a Teflon Liner Present in the Pressure Vessels . .

15 Radionuclide $\mathrm{Kd}$ ' Values Obtained With 0.30 to $0.85-\mathrm{mm}$ Umtanum Basalt at $150^{\circ} \mathrm{C}$ and $6.9 \mathrm{MPa} \mathrm{N} 2,1 \mathrm{~g}$ Basalt/10 ml Solution . .

B.1 The As-Received Chemical Composition of the Secondary Mineralization Use in the Radionuclide Distribution Determinations. 


\section{INTRODUCTION}

The objective of the work described in this annual report is to assist the Basalt Waste Isolation Program in completing a safety assessment of potential radionuclide migration from a repository mined in basalt to the biosphere. The time period covered by this report is February 1, 1979 to August 30, 1979.

Several parameters have been recognized as significant in the transport of radionuclides by groundwater through basalt. One of the most important parameters is the Kd (equilibrium distribution coefficient). A Kd may be defined as the tendency of a solute to distribute in equilibrium concentration between two immiscible phases at a constant temperature. Nernst first clearly stated this law in 1891. The ideal distribution law can be given as $K=A / B$, where $A$ and $B$ are the activities of the solute in the respective solvents, and $K$ is the ideal equilibrium distribution coefficient. In very dilute solutions, the activities of the solute in the two phases may be replaced by their molar concentrations. The ideal distribution law is a limiting case and holds only for ideal solutions. The distribution law is not confined to liquid solutions, but also is applicable to systems involving more than one physical phase such as the basalt-groundwater system. Factors affecting the Kd include temperature and pressure.

Pressure generaliy has little effect on the distribution ratio, while temperature can show a large effect in nonideal solutions or if the temperature coefficients of solubility of the solute are unequal in the two phases. Hence, the concept of a radionuclide ideal equilibrium distribution coefficient (Kd) is a valid one only within the narrow limits of the system: 1 ) at equilibrium, 2) reversible, 3) nearly ideal, and 4) isothermal.

To take these conditions in order, in systems that include basalt as the solid phase, the approach to equilibrium is very slow below temperatures of $100^{\circ} \mathrm{C}$. Also, demonstrating that equilibrium has been attained is very difficult. Silicate solubilities and reaction kinetics are very slow at room temperature. 
The sorption reaction resulting in the distribution coefficient is not always reversible. The sorption mechanism may involve the collapse of a $10 \mathrm{~A}$ layer structure, trapping the radionuclide in an energy well for many days. Another possibility is radionuclide precipitation due to exceeding the solubility limits of the hydration products. Americium and plutonium of ten yield high Kd values as a result of partial precipitation.

The near ideal conditions refer to the trace level of radionuclide concentration in this case. Above about $1 \times 10^{-7} \underline{M}$ cesium, for example, the $C s$ $K d$ concept is no longer valid due to a cesium concentration dependence. The upper limit of the trace concentration level must be determined for each radionuclide. All of the Kd values must be determined isothermally because the final solution composition is a function of the temperature.

Due to the above considerations, the radionuclide distribution coefficients discussed in this report are constrained by system temperature, contacting solution composition including $\mathrm{pH}$ and $\mathrm{Eh}$, radionuclide concentration and species and the basalt-solution approach to equilibrium. The last constraint led to the association of each radionuclide distribution coefficient with a solution-solid contact time. This coefficient is referred to as a Kd' with the dimensions of $\mathrm{ml}$ of solution/g of basalt. If the surface area/unit of the basalt is known, the $\mathrm{Kd}$ ' also could have the dimensions of $\mathrm{ml}$ of solution $/ \mathrm{m}^{2}$ of basalt.

The irmediate objective of this work is to determine the $K d^{\prime}$ values for americium, plutonium, neptunium, uranium, radium, cesium, strontium, selenium, technetium and iodine with basalt under conditions simulating those predicted for a repository in basalt. This report contains improvements in distribution coefficient precision and experimental $\mathrm{Kd}$ ' results at $23^{\circ} \mathrm{C}, 60^{\circ} \mathrm{C}$ and $150^{\circ} \mathrm{C}$.

Additional work on the basalt characterization includes surface area determinations and quantitative mineralogy of Flow $E$ and Pomona basalts (Appendix A). Preparation and some physical and chemical characteristics of the secondary mineralization used in the $K d^{\prime}$ determinations are given in Appendix $B$. The mechanics of an ethylene glycol adsorption surface area 
determination are recorded in Appendix C. Outlines of the $150^{\circ} \mathrm{C}$ and $300^{\circ} \mathrm{C}$ experiments in the pressure vessels are given in Appendices $D$ and $E$, respectively.

The Umtanum basalt was sampled at a surface location near Priest Rapids dam on the Columbia River (Hodge and Grutzeck 1978). As a surface outcropping, it has been subjected to a certain amount of weathering. The nature of this basalt surficial weathering is reported in Appendix $F$. 


\section{CONCLUSIONS}

Several general conclusions may be drawn from the $23^{\circ}, 60^{\circ}$ and $150^{\circ} \mathrm{C} \mathrm{Kd}$ ' results obtained to date. These conclusions are as follows:

- Iodine, neptunium and uranium $K d^{\prime}$ values for basalt ranged from 0 to $10 \mathrm{ml} / \mathrm{g}$ at $23^{\circ} \mathrm{C}$ and remain at nearly the same values to $150^{\circ} \mathrm{C}$. Secondary mineralization $K d^{\prime}$ data presently are insufficient to allow general conclusions. Technetium $K d^{\prime}$ values changed little from $23^{\circ} \mathrm{C}$ to $60^{\circ} \mathrm{C}$ for secondary mineralization or basalt.

- Cesium Kd' values for basalts decreased from $3100 \mathrm{ml} / \mathrm{g}$ at $23^{\circ} \mathrm{C}$ to $120 \mathrm{ml} / \mathrm{g}$ at $150^{\circ} \mathrm{C}$, probably due to increased basalt solubility and solution ionic strength with increased temperature. Strontium Kd' values increased with temperature probably due to sorption and burial on forming secondary mineral products.

- Plutonium Kd' values increased for the Pomona basalt and decreased for Flow $\mathrm{E}$ and Umtanum basalt from $23^{\circ} \mathrm{C}$ to $60^{\circ} \mathrm{C}$. At $150^{\circ} \mathrm{C}$, the Umtanum basalt $\mathrm{Kd}$ ' increased sharply from $180 \mathrm{ml} / \mathrm{g}$ at $60^{\circ} \mathrm{C}$ and 36 days to complete removal at $150^{\circ} \mathrm{C}$.

- Americium Kd' values for basalt decreased by about an order of magnitude from $23^{\circ} \mathrm{C}$ to $60^{\circ} \mathrm{C}$ (500 to $1000 \mathrm{ml} / \mathrm{g}$ to 35 to $63 \mathrm{ml} / \mathrm{g}$ ).

- Selenium $\mathrm{Kd}$ ' values for basalt increased from $3 \mathrm{ml} / \mathrm{g}$ at $23^{\circ} \mathrm{C}$ to $360 \mathrm{ml} / \mathrm{g}$ at $150^{\circ} \mathrm{C}$ and 45 days.

- Solutions in contact with basalt at $23^{\circ} \mathrm{C}$ tended to increase in $\mathrm{pH}$ with time from approximately $\mathrm{pH} 7$ to 8 to $\mathrm{pH} 8$ to 9.

- Oxygen contents of the solutions in contact with 0.30 to $0.85-\mathrm{mm}$ mesh basalts changed little in 31 days.

- Certain of the radionuclides are more readily removed by one basalt than by another. Technetium, for example, shows a $\mathrm{Kd}$ ' of 12 to $15 \mathrm{ml} / \mathrm{g}$ at $23^{\circ} \mathrm{C}$ and 30 to $40 \mathrm{ml} / \mathrm{g}$ at $60^{\circ} \mathrm{C}$ with Umtanum basalt. Flow $\mathrm{E}$ basalt technetium $\mathrm{Kd}$ ' was steady at $2 \mathrm{ml} / \mathrm{g}$ for $23^{\circ} \mathrm{C}$ and $60^{\circ} \mathrm{C}$. Pomona basalt $\mathrm{Kd}^{\prime}$ varied from 1 to $0 \mathrm{ml} / \mathrm{g}$ at $23^{\circ} \mathrm{C}$ and $60^{\circ} \mathrm{C}$ for technetium. 
- The empirical nature of Kd' measurements becomes readily apparent as the affects of temperature changes on resulting $K d^{\prime}$ ' changes is observed. Kd' values rise and fall in response to presently unknown reactions between the solution, basalt and radionuclide. 


\section{DISTRIBUTION COEFFICIENT PRECISION IMPROVEMENT}

One of the primary goals of the laboratory distribution coefficient work is to improve the precision of the $K d^{\prime}$ data obtained with the batch contact methodology used in these determinations. There are two ways to improve $\mathrm{Kd}^{\prime}$ values. These are through improvements in the laboratory techniques used in $K d^{\prime}$ determinations and through the use of replication of $K d^{\prime}$ determinations.

\section{EXPER IMENTAL METHODOLOGY IMPROVEMENT}

A batch $K d^{\prime}$ measurement is made by contacting a known volume and composition of solution containing a radionuclide at trace level concentration with a weighed solid for a known length of time. At the finish of solid-solution contact, an aliquot of the solution is separated from the solid by centrifugation or filtration, and the radionuclide is counted and compared to a blank solution (an equal volume of the original solution containing no solids). The radioactivity on the solid is not usually directly counted, but is determined by subtracting the radioactivity in a volume of equilibrium solution from the radioactivity in an equal volume of blank solution. The $K d^{\prime}$ (based on mass) is the radionuclide concentration per gram of solid divided by the radionuclide concentration per milliliter of equilibrium solution at time $t$, and has dimensions of $\mathrm{ml} / \mathrm{g}$.

One of the problem areas of batch $K d^{\prime}$ measurement is that of solidssolution separation prior to counting. Certain radionuclides, such as those of cesium, can become adsorbed on colloidal and larger-size particles, remain in the solution through the solids separation procedure, and result in a much lower computed $\mathrm{Kd}^{\prime}$ value for the radionuclide. If the radionuclide is not strongly adsorbed by the very fine to colloidal particulates, a poor solidsolution separation procedure have little to no effect on the derived Kd' value because no high activity solids are contained in the counting aliquot. Cesium is one of the elements that have shown a direct relationship between suspended solids concentration and the percentage of the total cesium in the system adsorbed on them (Eichholz et al. 1967). 
An example of difficulties with solid-solution separations is given in Table 1 and Figure 1, where the total amounts of cesium and suspended solids in the system were varied by changing the solution volume to clay weight ratio used. The less than two micrometer $(<2 \mu \mathrm{m})$ nontronite, a common basalt weathering product, was purposely inadequately separated from its contacting solution before cesium-137 counting. The resulting cesium $\mathrm{Kd}$ ' values varied considerably with the solution volume to solid weight ratio. The actual cesium $\mathrm{Kd}^{\prime}$ value obtained with a good solution-solid separation was about $1380 \mathrm{ml} / \mathrm{g}$. Later filtration of the solids-contaminated, $10 \mathrm{ml}$ to $1 \mathrm{~g}$ solution volume to solid weight ratio solution volume yielded a cesium 30-day Kd' value of $1339 \pm 166 \mathrm{ml} / \mathrm{g}$. Hence, with proper solid-solution separations, it is possible to obtain the same cesium $\mathrm{Kd}^{\prime}$ value. Filtration of the $80 \mathrm{ml}$ to $1 \mathrm{~g}$ ratio aliquot did not appreciably change its cesium Kd' value, probably because this aliquot contained 8 times as much cesium as the $10 \mathrm{ml}$ to $1 \mathrm{~g}$ ratio aliquot and the same weight of clay. Although the clay adsorbed as much cesium in both aliquots, the fraction of the total cesium in the system adsorbed by the clay in the $80 \mathrm{ml}$ to $1 \mathrm{~g}$ ratio aliquot was minor.

The same problem with poor solid-solution separations also was encountered using basalt rocks as the solid. Umtanum basalt cesium $\mathrm{Kd}$ ' values were checked with the same variable solution volume to solid weight ratio procedure with the results shown in Table 2 and Figure 2. Much larger solution volume to solid weight ratios were required to approach the true cesium $\mathrm{Kd}$ ' value of about $3100 \mathrm{ml} / \mathrm{g}$ shown as a dotted line in Figure 2. Filtration through a 0.015-um filter did not appreciably change any of the cesium Kd' values, which suggests that the suspended particulates were colloidal in size. Since the 20- to 50 -mesh ( 0.85 to $0.30 \mathrm{~mm}$ ) Umtanum basalt was thoroughly washed before use on a 50-mesh screen, it must be assumed that the colloidal pariculates were generated by abrasion during sample agitation. The greater the weight of basalt per unit volume (the lower the solution volume to solid weight ratio), the more frequent were the collisions between basalt solids per unit time and the more colloidal particulates produced. As the solution volume to solid weight ratio increased, the collision frequency between basalt solids decreased; the total amount of cesium in the system also increased until a true cesium Kd' value was approached at $3100 \mathrm{ml} / \mathrm{g}$. 
TABLE 1. The Less Than Two Micrometer, Freeze-Dried Nontronite/Cesium 30-Day Kd'Variations With Solution to Solid Ratio and Equilibrium Solution Treatment

Solution Volmue to Solid Weight Ratio, $\mathrm{ml} / \mathrm{g}$ $10 / 1$

$30 / 1$

$60 / 1$

$80 / 1$
Centrifuged, 1000 grav., 15 min.

$$
\begin{aligned}
755 & \pm 115 \\
1135 & \pm 237 \\
1349 & \pm 26 \\
1407 & \pm 22
\end{aligned}
$$

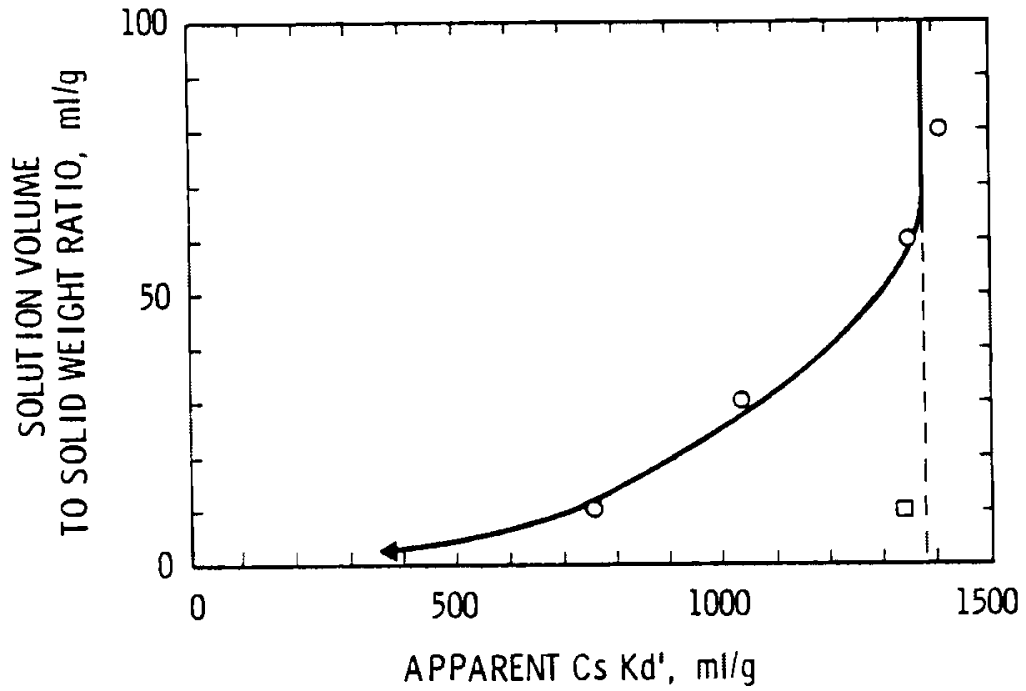

Initial Cs Filtered, Concentration, $\frac{0.015 \mu \mathrm{m}}{1339+166} \frac{\text { Moles } / \ell}{1.83 \times 10^{-9}}$ $=1.83 \times 10^{-9}$

$-1.83 \times 10^{-9}$

FIGURE 1. Apparent Cesium Kd' Variation of $<2 \mu \mathrm{m}$ Nontronite at Several Solution to Solid Ratios and 30 Days Equilibrium Time With Shaking. The square represents $\mathrm{Kd}^{\prime}$ value of the $0.015-\mu \mathrm{m}$ filtered sample. (Agitation Rate $=125 \mathrm{cycles} / \mathrm{min}$ )

Another area of study was the minor element chemistry of synthetic groundwater equilibrated with 0.85 to $0.30 \mathrm{~mm}$ Umtanum basalt. Experiments suggested that suspended colloidal particles generated during the agitation used in solution-solid equilibrations were the source of iron in the ICP solution analys is as well as the cesium Kd' variation. The inductively coupled plasma spectrographic (ICP) analytical results are shown in Table 3 . The solution was filtered through a $0.45-\mu \mathrm{m}$ filter to remove the larger suspended particles and allow determination of any suspended colloids during the ICP analys is. 
TABLE 2. Umtanum Basalt $23^{\circ} \mathrm{C}$ Cesium Kd' Variation With Solution Volume to Solid Weight Ratio (Agitation Rate $=125 \mathrm{cycles} / \mathrm{min}$ )

\begin{tabular}{cccc}
$\begin{array}{c}\text { Solution Volume } \\
\text { to Solid Weight } \\
\text { Ratio, ml/g }\end{array}$ & $\begin{array}{c}30 \text {-Day Cs Kd', } \\
23^{\circ} \mathrm{C}, 0.45 \mu \mathrm{m} \\
\text { Filtered, } \mathrm{ml} / \mathrm{g}\end{array}$ & $\begin{array}{c}\text { Initial Cs } \\
\begin{array}{c}\text { Concentration, } \\
\text { Moles } / 2\end{array}\end{array}$ \\
\cline { 1 - 1 } $10 / 1$ & & $321 \pm 39$ & $1.83 \times 10^{-9}$ \\
$30 / 1$ & $828 \pm 36$ & $1.83 \times 10^{-9}$ \\
$60 / 1$ & $1624 \pm 121$ & $1.83 \times 10^{-9}$ \\
$80 / 1$ & $2203 \pm 53$ & $1.83 \times 10^{-9}$ \\
$200 / 1$ & $2876 \pm 232$ & $1.83 \times 10^{-9}$ \\
$400 / 1$ & $3126 \pm 1048$ & $1.83 \times 10^{-9}$ \\
$600 / 1$ & $3048 \pm 749$ & $1.83 \times 10^{-9}$
\end{tabular}

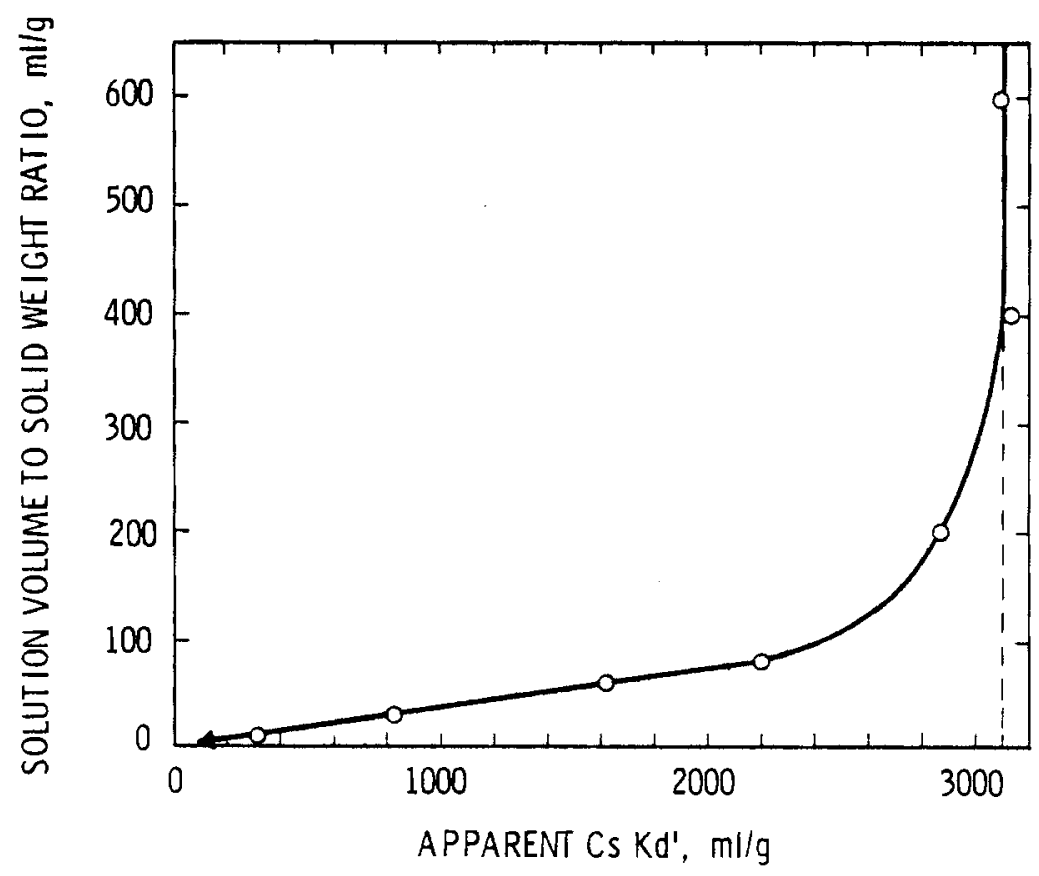

FIGURE 2. Apparent Cesium Kd' Variation for Umtanum Basalt at Several Solution to Solid Ratios and 30 Days Equilibrium Time With Shaking (Agitation Rate $=125$ cycles $/ \mathrm{min}$ ) 
Iron and manganese apparently increased in concentration in the equilibrium solution as seen in Table 3 . The solubility of ferric iron in $\mathrm{pH} 8.0$ solutions $\left(K_{\text {so }}=-38.6\right.$, Sillen 1971$)$ is rather low at approximately $10^{-20} \mathrm{M}$ at $25^{\circ} \mathrm{C}$, while the $0.2 \mathrm{mg} \mathrm{Fe} / \mathrm{l}$ given in Table 3 is $3.58 \times 10^{-6}$ in molarity. The solubility of ferrous iron is much greater at $\mathrm{pH} 8.0$, but in this oxygenated solution, the life of ferrous iron can be assumed to be very short. The 108-day equilibration solution, therefore, should have contained no measurable iron in solution. A colloid consisting at least partly of hydrated ferric oxide-hydroxide and similar manganese solids probably was present in the solution. The cesium would adsorb on these high surface area materials producing a low Cs Kd' value due to failure to separate these materials from the final solution to be counted.

TABLE 3. ICP Trace Element Analys is of the Original and 108-Day Equilibrating Solution With Umtanum Basalt. Solution volume to basalt weight ratio was $5 \mathrm{ml} / \mathrm{g}$. Fluorine analys is was by ion chromatography. A general wt\% error for all analyses was \pm 10 .

\begin{tabular}{|c|c|c|c|}
\hline \multicolumn{2}{|c|}{ Original Solution } & \multicolumn{2}{|c|}{$\begin{array}{l}\text { 108-Day Solution, } \\
0.45 \mu \mathrm{m} \text { Filtration } \\
\end{array}$} \\
\hline Constituent & Content, $\mathrm{ppm}$ & Constituent & Content, $\mathrm{ppm}$ \\
\hline Al & $<0.10$ & Al & 0.10 \\
\hline As & $<0.01$ & As & 0.02 \\
\hline B & 0.01 & B & 0.02 \\
\hline $\mathrm{Ba}$ & $<0.01$ & $\mathrm{Ba}$ & 0.01 \\
\hline $\mathrm{Fe}$ & $<0.01$ & $\mathrm{Fe}$ & 0.20 \\
\hline$P$ & $<0.05$ & $P$ & 0.10 \\
\hline$S r$ & 0.01 & $\mathrm{Sr}$ & 0.03 \\
\hline $\mathrm{Mn}$ & $<0.01$ & $\mathrm{Mn}$ & 0.40 \\
\hline $\mathrm{Se}$ & $<0.10$ & $\mathrm{Se}$ & $<0.10$ \\
\hline Th & $<0.10$ & Th & $<0.10$ \\
\hline$U$ & $<0.01$ & U & $<0.01$ \\
\hline$F$ & 0.06 & $F$ & 0.30 \\
\hline \multicolumn{2}{|c|}{$\mathrm{pH}=8.0$} & \multicolumn{2}{|c|}{$\mathrm{pH}=8.0$} \\
\hline
\end{tabular}


Several revisions to the experimental technique for solution-solid equilibration were investigated to avoid the particulates generation problem, but the simplest was to lower the shaker agitation rate from 125 cycles/min to 50 or 60 cycles/min. The lower agitation rate was still adequate to maintain good solution-solid contact while preventing particulate generation. Sorption data for cesium on the same Umtanum basalt at the lower agitation rate is presented in Table 4.

\section{REPLICATION}

Another way to improve precision of the radionuclide distribution coefficient results is by replication of $\mathrm{Kd}^{\prime}$ measurements. Six samples were equilibrated in the $23^{\circ} \mathrm{C}, 60^{\circ} \mathrm{C}$ and anoxic experiments in two sets of three samples each. Differing experimental conditions were represented by the two sets. One set contained relatively high concentrations of radionuclides while the other set contained relatively low radionuclide concentrations, although both were within the trace level of concentration where the $K d^{\prime}$ remains the same.

The solution volume to solid weight was $100 \mathrm{ml} / \mathrm{g}$ for one set and $10 \mathrm{ml} / \mathrm{g}$ for the other set. Neither the changes in solution volume to solid weight ratio nor the changes in tracer concentration level should affect $\mathrm{Cs}$ or $\mathrm{Sr} \mathrm{Kd}^{\prime}$ values on basalts. If $\mathrm{Kd}^{\prime}$ effects are noted between the two sets, they are due to experimental problems. Hence, the two data sets furnish a method of checking the experimental procedure as well as furnishing additional replicates to improve $\mathrm{Kd}^{\prime}$ precision.

An example of such a dual set of experiments is shown in Table 4 and Figures 3 and 4 . The mean cesium $K d^{\prime}$ value for Umtanum basalt was about $3100 \mathrm{ml} / \mathrm{g}$ and the mean strontium $\mathrm{Kd}^{\prime}$ value about $105 \mathrm{ml} / \mathrm{g}$. The mean $\mathrm{Kd}^{\prime}$ values were approached slowly, and later measured Kd' values tended to oscillate about them.

One problem with $\mathrm{Kd}^{\prime}$ determinations that is inherent in the system can be discerned in Figure 3. Counting statistics becomes a major factor when the Kd' values are much above 1000 or close to zero, especially with matrixcorrected values such as those represented in Figure 3. The matrix-corrected 
TABLE 4. Kd' Values for Umtanum Basalt at $23 \mathrm{C}$ Under Two Sets of Experimental Conditions

\section{Condition I}

$100 \mathrm{ml}$ Solution/1 g Basalt, Contained in $202 \mathrm{~m}$ Polyethylene Mesh, 50 Cycles/Min Agitation, $2580 \mathrm{cpm}{ }^{137} \mathrm{Cs}+360 \mathrm{cpm}{ }^{85} \mathrm{Sr}$, Mean of 3 Samples And a Standard Deviation Estimate (1 s).

\begin{tabular}{|c|c|c|c|c|c|c|c|}
\hline \multirow{3}{*}{$\frac{\text { Radionuclide }}{137 \mathrm{Cs}}$} & \multicolumn{7}{|c|}{$\mathrm{Kd}^{\prime}, \mathrm{ml} / \mathrm{g}$} \\
\hline & 5 Days & 10 Days & 15 Days & 20 Days & 25 Days & 36 Days & 41 Days \\
\hline & $280 \pm 49$ & $2022 \pm 44$ & $2903 \pm 210$ & $2755 \pm 168$ & $2789 \pm 104$ & $2780 \pm 105$ & $3058 \pm 214$ \\
\hline${ }^{85} \mathrm{sr}$ & $27 \pm 0.6$ & $85 \pm 18$ & $82 \pm 9$ & $88+5$ & $98 \pm 7$ & $97 \pm 3$ & $111+12$ \\
\hline
\end{tabular}

\section{Condition II} $10 \mathrm{ml}$ Solution $/ 1 \mathrm{~g}$ Basalt, No Sample Containment, 50 Cycles/Min Agition, 60,000 $\mathrm{cpm}$
$137 \mathrm{Cs}+21,300 \mathrm{cpm} 85 \mathrm{Sr}$, Mean of 4 Samples Plus a Standard Deviation Estimate (1 s).

$\begin{array}{cccccc}\frac{\text { Radionuclide }}{{ }_{137}{ }_{\mathrm{Cs}}} & \frac{7 \text { Days }}{714 \pm 55} & \frac{14 \text { Days }}{1408 \pm 126} & \frac{21 \text { Days }}{1828 \pm 56} & \frac{27 \text { Days }}{2869 \pm 252} & \frac{32 \text { Days }}{3216 \pm 187} \\ { }^{85} \mathrm{Sr} & 57 \pm 1 & 72 \pm 2 & 78 \pm 3 & 88 \pm 3 & 92 \pm 2\end{array}$




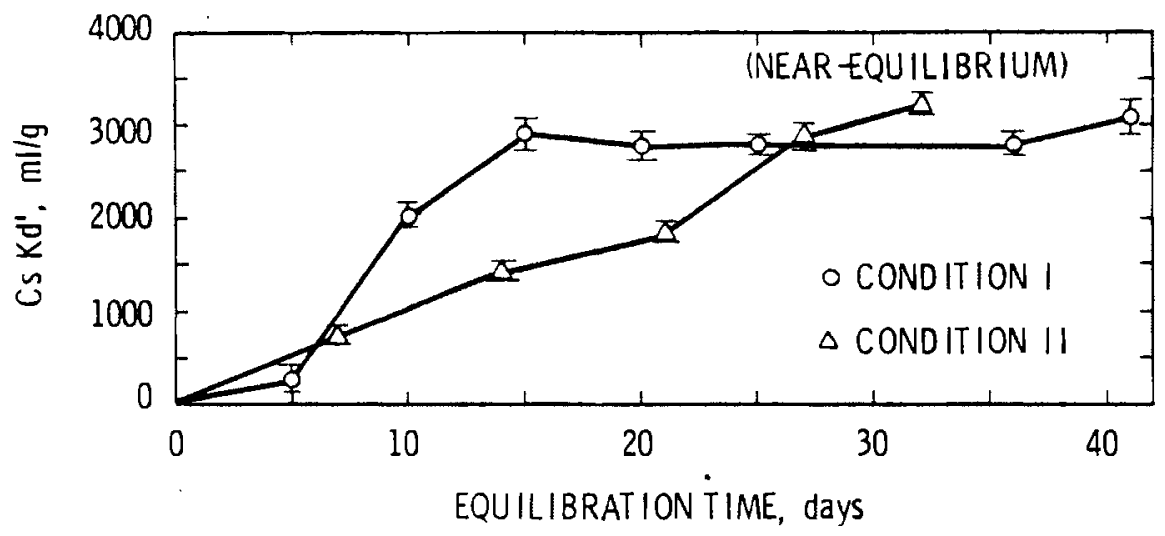

FIGURE 3. Cesium Kd' Values Versus Equilibration Time at $23^{\circ} \mathrm{C}$ for Umtanum Basalt and Synthetic Groundwater GR-1. The two sets of experimental conditions are given in Table 4.

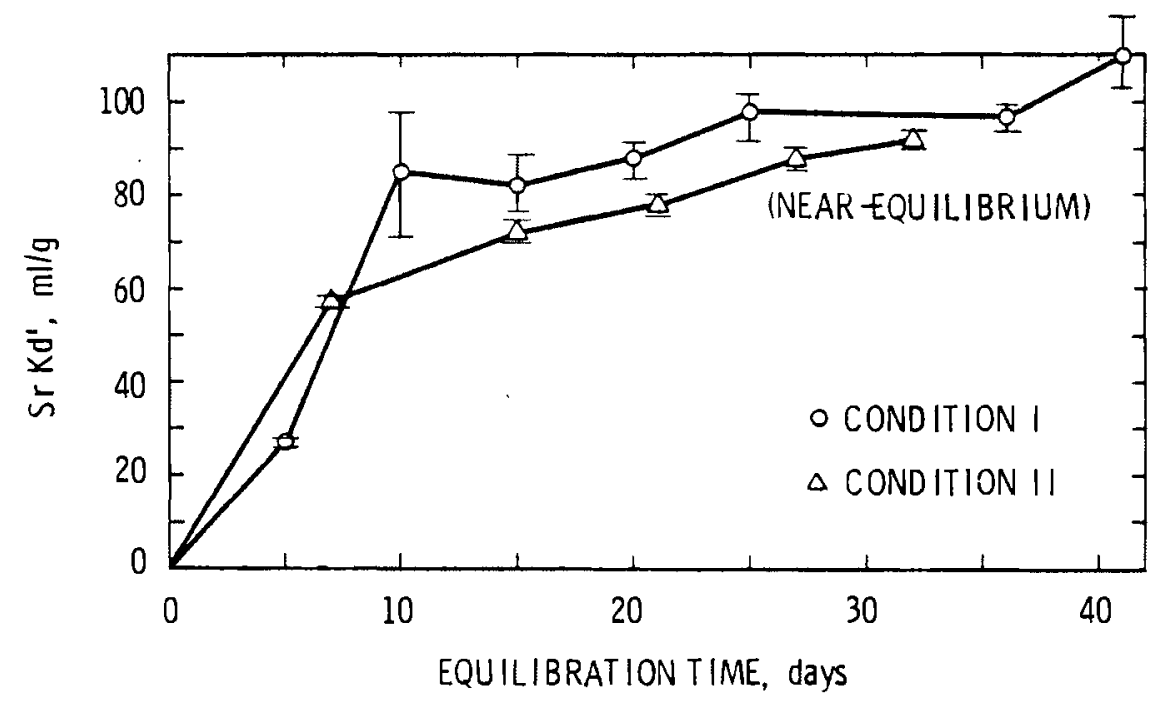

FIGURE 4. Strontium Kd' Values Versus Equilibration Time at $23^{\circ} \mathrm{C}$ for Umtanum Basalt and Synthetic Groundwater. The two sets of experimental conditions are given in Table 4. 
${ }^{137}$ Cs value for the nonagitated samples, for example, was 200,000 counts/ $200 \mathrm{sec}$ mean for the blank solutions and 560 counts/200 sec mean for the equilibrated solutions. A variation of 10 counts in the latter mean yields a variation of nearly $100 \mathrm{ml} / \mathrm{g}$ in the $\mathrm{Kd}$ ' values. Hence, with very high and very low radionuclide adsorption, care must be taken to include several $\mathrm{Kd}$ ' measurements to improve precision.

With the two sets of radionuclide Kd' data, six replicates of each Kd' value were generated, leading to improvements in $\mathrm{Kd}$ ' value precision for the $23^{\circ}$ and $60^{\circ} \mathrm{C}$ experiments. The $150^{\circ} \mathrm{C}$ and $300^{\circ} \mathrm{C}$ experiments are expected to reach near-equilibrium relatively rapidly ( 30 to 45 days). Successive, single $K d^{\prime}$ values at $150^{\circ}$ and $300^{\circ} \mathrm{C}$ serve the same purpose of improving $K d^{\prime}$ precision as do replicate experiments at $23^{\circ}$ and $60^{\circ} \mathrm{C}$. 


\section{EXPERIMENTAL RESULTS}

Radionuclide distribution coefficients were determined in Inconel $300 \mathrm{ml}$ pressure vessels at $150^{\circ} \pm 2^{\circ} \mathrm{C}$. The $60^{\circ} \mathrm{C}$ experiments were performed in incubator-shakers with heated, recirculated atmospheres. An investigation of $300^{\circ} \mathrm{C}$ radionuclide distribution coefficients also is under way, but no experimental Kd' results were obtained in FY-1979. Two $500 \mathrm{~m} 1$ Inconel pressure vessels are on order for the $300^{\circ} \mathrm{C}$ work with basalts and secondary minerals. The $\mathrm{Kd}$ ' results that were obtained are reported under their respective temperatures. The 20 to 50 mesh $(0.85$ to $0.30 \mathrm{~mm})$ crushed basalts were used in the $\mathrm{Kd}^{\prime}$ work unless otherwise specified.

\section{$23^{\circ} \mathrm{C}$ STATIC Kd EXPERIMENTS}

The methodology used in the $23^{\circ} \mathrm{C}$ experiments was given in PNL-3103 (Ames and McGarrah 1979). The synthetic groundwater-formulation used in the Kd determinations is given in Table 5. Briefly, a weighed solid was contacted with a known volume of solution containing a radionuclide. After a known contact time, the solution and solid phase were separated and the solution activity counted. The radionuclide concentration remaining in this solution was compared to that contained in a blank solution which never contacted a solid sample (basalt or secondary mineralization), and a $\mathrm{Kd}$ ' value was computed. Two solid weight to solution volume ratios were used: $1 \mathrm{~g} / 10 \mathrm{ml}$ and $1 \mathrm{~g} / 80 \mathrm{ml}$. The $1 \mathrm{~g} / 80 \mathrm{ml}$ ratio contained a greater radionuclide concentration as the $1 \mathrm{~g} / 10 \mathrm{ml}$ ratio experiments. The $\mathrm{Kd}$ ' values from both ratios should eventually converge, provided that both radionuclide concentrations are within the stable $K d^{\prime}$ range and the experimental conditions are otherwise comparable.

The initial $\mathrm{Kd}$ ' results are shown in Tables 6,7 and 8 for several contact times. Each $K d^{\prime}$ value is a mean of three $K d^{\prime}$ 'experiments, and the plus or minus value is an estimate of the standard deviation (1 s).

Many of the 58- and 83-day $K d^{\prime}$ 'values shown in Table 6 were quite similar. Most of the radionuclides that yielded similar 58-and 83-day $\mathrm{Kd}^{\prime}$ values were those little affected by system macrochemistry changes such as the 
TABLE 5. Synthetic Groundwater Formulation GR-1

\begin{tabular}{|c|c|c|c|}
\hline Constituents & $\begin{array}{c}\text { Concentration, } \\
\mathrm{mg} / \mathrm{i}\end{array}$ & $\begin{array}{l}\text { Chemical } \\
\text { Compound }\end{array}$ & $W t, m g / 1$ \\
\hline $\mathrm{Na}^{+}$ & 30.7 & $\mathrm{NaHCO}_{3}$ & 112.2 \\
\hline $\mathrm{k}^{+}$ & 9.0 & $\mathrm{~K}_{2} \mathrm{SO}_{4}{ }^{\circ}$ & 20.1 \\
\hline $\mathrm{Ca}^{2+}$ & 6.5 & $\mathrm{CaCl}_{2} \cdot 2 \mathrm{H}_{2} \mathrm{O}$ & 23.8 \\
\hline $\mathrm{Mg}^{2+}$ & 1.0 & $\mathrm{MgCl}_{2}^{2} \cdot 6 \mathrm{H}_{2}^{2} \mathrm{O}$ & 8.4 \\
\hline $\mathrm{Cl}^{-}$ & 14.4 & $\mathrm{SiO}_{2}$ (Amorphous) & 25 \\
\hline $\mathrm{CO}_{3}^{2-}$ & 0 & & \\
\hline $\mathrm{HCO}_{3}=$ & 81.5 & & \\
\hline $\mathrm{F}^{-3}$ & 0 & & \\
\hline $\mathrm{SO}_{4}^{2-}$ & 11.1 & & \\
\hline $\mathrm{SiO}_{2}$ & 8.0 & & \\
\hline
\end{tabular}

anionic species of selenium, technetium, iodine, and uranium. The contact times for the $1 \mathrm{~g}$ basait/80 $\mathrm{ml}$ solution ratio $\mathrm{Kd}$ ' values and those for the secondary mineralization are too short to draw similar conclusions based on the data of Tables 7 and 8 .

Even though the 2.00 to $0.85 \mathrm{~mm}$ and 0.30 to $0.85 \mathrm{~mm}$ Pomona basalts are considerably different in grain size range, they are nearly comparable in surface areas (see Appendix A). In most cases, the Kd' values of the two Pomona grain size ranges for specific radionuclides also are very similar. Only the cesium, americium, and plutonium experiments of Table 5 are still monitored on a monthly basis. Monthly monitoring of the $1 \mathrm{~g}$ basalt/80 $\mathrm{ml}$ solution samples (Table 7) and the secondary mineralization samples (Table 8 ) also is continuing.

Except for cesium, americium, and plutonium, the radionuclide experiments reported in Table 6 were set aside and the $\mathrm{pH}$ of randomly selected blanks and basalt-containing solutions was taken. The pH values are reported in Table 9. In general, the $\mathrm{pH}$ values of the basalt-containing solutions tended to rise 
TABLE 6 . The $23^{\circ} \mathrm{C}, 1 \mathrm{~g} / 10 \mathrm{ml}$ Solution $K d^{\prime}$ Values for Basalts and Synthetic Groundwater GR-1

\begin{tabular}{|c|c|c|c|c|c|c|c|}
\hline \multirow{3}{*}{$\frac{\text { Radionuc lide }}{75 \mathrm{Se}}$} & \multicolumn{6}{|c|}{$\mathrm{Kd}, \mathrm{ml} / \mathrm{g}$} & \multirow[b]{2}{*}{$\begin{array}{l}\text { Tracer Initial } \\
\text { Conc., } M \\
\end{array}$} \\
\hline & $\begin{array}{l}\text { Umtanum } \\
\text { Basalt }\end{array}$ & $\begin{array}{l}\text { Flow E } \\
\text { Basalt }\end{array}$ & $\begin{array}{l}\text { Pomona } \\
2.00 \text { to }\end{array}$ & $\begin{array}{l}\text { Basalt, } \\
0.85 \mathrm{~mm}\end{array}$ & $\begin{array}{l}\text { Pomona Basalt, } \\
0.30 \text { to } 0.85 \mathrm{~mm}\end{array}$ & $\begin{array}{l}\text { Contact } \\
\text { Time, Days } \\
\end{array}$ & \\
\hline & $5 \pm 0.3$ & $2 \pm 0.3$ & & 0 & 0 & 31 & $1.74 \times 10^{-12}$ \\
\hline & $5 \pm 0.3$ & $3 \pm 0.6$ & & 0 & 0 & 58 & \\
\hline & $4 \pm 0.4$ & $3 \pm 0.3$ & & 0 & 0 & 83 & \\
\hline${ }^{85} \mathrm{sr}$ & $92 \pm 2$ & $72 \pm 2$ & 102 & \pm 14 & $102 \pm 14$ & 31 & $1.26 \times 10^{-12}$ \\
\hline & $103 \pm 3$ & $96 \pm 3$ & 133 & \pm 11 & $138 \pm 11$ & 58 & \\
\hline & $105 \pm 3$ & $102 \pm 3$ & 136 & \pm 2 & $137 \pm 7$ & 83 & \\
\hline${ }^{99} \mathrm{TC}$ & $15 \pm 5$ & $2 \pm 1$ & 0.2 & \pm 0.1 & $0.2 \pm 0.1$ & 31 & $4.19 \times 10^{-6}$ \\
\hline & $13 \pm 4$ & $2 \pm 1$ & 0.1 & \pm 0.04 & $0.1 \pm 0.1$ & 58 & \\
\hline & $12 \pm 3$ & $2 \pm 1$ & & 0 & 0 & 83 & \\
\hline $125 \mathrm{I}$ & $1.3 \pm 0.3$ & $0.3 \pm 0.03$ & 0.3 & \pm 0.1 & $0.3 \pm 0.1$ & 31 & $7.24 \times 10^{-13}$ \\
\hline & $1.8 \pm 0.2$ & $0.4 \pm 0.1$ & 0.7 & \pm 0.2 & $0.7 \pm 0.2$ & 58 & \\
\hline & $3.1 \pm 0.5$ & $0.5 \pm 0.3$ & 0.7 & \pm 0.1 & $0.5 \pm 0.4$ & 83 & \\
\hline${ }^{137} \mathrm{Cs}$ & $1247 \pm 306$ & $600 \pm 111$ & 1581 & \pm 90 & $1917 \pm 332$ & 31 & $1.83 \times 10^{-9}$ \\
\hline & $1927 \pm 92$ & $920 \pm 144$ & 2437 & \pm 219 & $3166 \pm 202$ & 58 & \\
\hline & $1663 \pm 31$ & $753 \pm 79$ & 2057 & \pm 124 & $2408 \pm 203$ & 83 & \\
\hline${ }^{226} \mathrm{Ra}$ & $67 \pm 2$ & $52 \pm 4$ & 56 & \pm 1 & $58 \pm 5$ & 31 & $1.31 \times 10^{-7}$ \\
\hline & $39 \pm 2$ & $32 \pm 7$ & 32 & \pm 2 & $36 \pm 2$ & 58 & \\
\hline & $64 \pm 3$ & $48 \pm 3$ & 52 & \pm 3 & $54 \pm 2$ & 83 & \\
\hline${ }^{237} \mathrm{~Np}$ & $8 \pm 1$ & $3 \pm 1$ & 4 & \pm 0 & $5 \pm 1$ & 31 & $1.62 \times 10^{-6}$ \\
\hline & $10 \pm 2$ & $5 \pm 1$ & 4 & \pm 0.3 & $6 \pm 1$ & 58 & \\
\hline & $9 \pm 1$ & $4 \pm 0.3$ & & \pm 0.6 & $5 \pm 0.8$ & 83 & \\
\hline${ }^{238} 8_{U}$ & 0 & $5 \pm 3$ & & 0 & 0 & 31 & $1.01 \times 10^{-6}$ \\
\hline & 0 & $4 \pm 0$ & & 0 & 0 & 58 & \\
\hline & & & & & & 83 & \\
\hline $241_{A m}$ & $2113 \pm 689$ & $738 \pm 336$ & 904 & \pm 637 & $883 \pm 173$ & 31 & $2.31 \times 10^{-8}$ \\
\hline & $658 \pm 294$ & $578 \pm 331$ & 278 & \pm 65 & $625 \pm 14$ & 58 & \\
\hline & $1265 \pm 1230$ & $536 \pm 458$ & 467 & \pm 173 & $831 \pm 116$ & 83 & \\
\hline & $418 \pm 189$ & $213 \pm 72$ & 341 & \pm 115 & $732 \pm 109$ & 107 & \\
\hline${ }^{24} 1_{\mathrm{Pu}}$ & $660 \pm 682$ & $142 \pm 33$ & 64 & \pm 44 & $83 \pm 3$ & 5 & $1.50 \times 10^{-10}$ \\
\hline & $602 \pm 113$ & $748 \pm 194$ & 88 & \pm 27 & $77 \pm 47$ & 32 & \\
\hline & $790 \pm 280$ & $147 \pm 60$ & 17 & \pm 2 & $68 \pm 31$ & 57 & \\
\hline & $2597 \pm 77$ & $254 \pm 345$ & 45 & \pm 22 & $90 \pm 23$ & 107 & \\
\hline
\end{tabular}


TABLE 7. The $23^{\circ} \mathrm{C}, 1 \mathrm{~g} / 80 \mathrm{ml}$ Solution Kd' Values for Basalts and Synthetic Groundwater GR-1

\begin{tabular}{|c|c|c|c|c|c|c|}
\hline \multirow{3}{*}{$\begin{array}{l}\text { Radio- } \\
\text { nuclide } \\
\frac{{ }^{75} \mathrm{Se}}{}\end{array}$} & \multicolumn{4}{|c|}{$\mathrm{Kd}^{\prime}, \mathrm{ml} / \mathrm{g}$} & \multirow[b]{2}{*}{$\begin{array}{l}\text { Contact } \\
\text { Time, } \\
\text { Days } \\
\end{array}$} & \multirow[b]{2}{*}{$\begin{array}{c}\text { Initial } \mathrm{Cs} \\
\text { Conc., } \mathrm{M} \\
\end{array}$} \\
\hline & $\begin{array}{l}\text { Umtanum } \\
\text { Basalt }\end{array}$ & $\begin{array}{l}\text { Flow E } \\
\text { Basalt }\end{array}$ & Pomona & Basalt, & & \\
\hline & $0.8 \pm 0.7$ & 0 & & 0 & 14 & $3.03 \times 10^{-12}$ \\
\hline \multirow{4}{*}{${ }^{85} \mathrm{Sr}$} & 0 & $9 \pm 2$ & & 0 & 39 & \\
\hline & 0 & $8 \pm 1$ & & 0 & 63 & \\
\hline & $95 \pm 7$ & $76 \pm 4$ & 152 & \pm 4 & 14 & $1.48 \times 10^{-12}$ \\
\hline & $126 \pm 13$ & $99 \pm 2$ & 180 & \pm 8 & 39 & \\
\hline \multirow{3}{*}{${ }^{99} \mathrm{TC}$} & $134 \pm 14$ & $99 \pm 3$ & 183 & \pm 10 & 63 & \\
\hline & $1.6 \pm 0.4$ & $2.3 \pm 1.4$ & 1.0 & \pm 0.2 & 14 & $1.07 \times 10^{-5}$ \\
\hline & 0 & 0 & 0.7 & \pm 3 & 39 & \\
\hline \multirow{3}{*}{${ }^{125_{I}}$} & $1.9 \pm 1.0$ & $1.1 \pm 0.3$ & 0.8 & \pm 0.5 & 63 & \\
\hline & $8 \pm 0.4$ & $9 \pm 4$ & & 0 & 14 & $1.39 \times 10^{-12}$ \\
\hline & $2.1 \pm 1.5$ & 0 & & 0 & 39 & \\
\hline \multirow{3}{*}{${ }^{137} \mathrm{Cs}$} & $7.3 \pm 2.4$ & $1.3 \pm 0.5$ & 5.5 & \pm 1.9 & 63 & \\
\hline & $911 \pm 87$ & $355 \pm 21$ & 1,346 & \pm 85 & 14 & $3.52 \times 10^{-9}$ \\
\hline & $1,524 \pm 195$ & $500 \pm 11$ & 1,868 & \pm 159 & 39 & \\
\hline \multirow{3}{*}{${ }^{226} \mathrm{Ra}$} & $1,837 \pm 187$ & $526 \pm 14$ & 2,183 & \pm 119 & 63 & \\
\hline & $178 \pm 89$ & $108 \pm 8$ & 150 & \pm 26 & 14 & $1.91 \times 10^{-7}$ \\
\hline & $241 \pm 2$ & $161 \pm 2$ & 201 & \pm 5 & 39 & \\
\hline \multirow{3}{*}{${ }^{237} \mathrm{~Np}$} & $211 \pm 2$ & $146 \pm 4$ & 172 & \pm 2 & 63 & \\
\hline & $20 \pm 5$ & $14 \pm 3$ & 14 & \pm 3 & 14 & $2.43 \times 10^{-6}$ \\
\hline & $27 \pm 2$ & $19 \pm 4$ & 11 & \pm 4 & 39 & \\
\hline \multirow[b]{2}{*}{${ }^{238} U$} & $28 \pm 2$ & $17 \pm 4$ & 11 & \pm 3 & 63 & \\
\hline & $\overline{0}$ & $6 \pm 1$ & & $\overline{0}$ & 14 & $1.86 \times 10^{-6}$ \\
\hline \multirow[b]{2}{*}{${ }^{241} \mathrm{Am}$} & $34 \pm 15$ & $8 \pm 4$ & & \pm 2 & 39 & \\
\hline & $5,800 \pm 3,000$ & $3,700 \pm 1,700$ & 3,300 & $\pm 1,300$ & 14 & $1.50 \times 10^{-8}$ \\
\hline \multirow{5}{*}{${ }^{241} 1_{P u}$} & $20,300 \pm 5,000$ & $29,200 \pm 8,000$ & 15,800 & $\pm 6,300$ & 39 & \\
\hline & $28,900 \pm 4,100$ & $38,400 \pm 25,100$ & 28,400 & $\pm 11,600$ & 63 & \\
\hline & $2,141 \pm 605$ & $1,260 \pm 316$ & 518 & \pm 188 & 14 & $1.83 \times 10^{-10}$ \\
\hline & $4,425 \pm 700$ & $2,699 \pm 419$ & 262 & \pm 154 & 39 & \\
\hline & $4,199 \pm 697$ & $2,548 \pm 267$ & 171 & \pm 115 & 63 & \\
\hline
\end{tabular}


TABLE 8. The $23^{\circ} \mathrm{C} \mathrm{Kd'} \mathrm{Values} \mathrm{for} \mathrm{Secondary} \mathrm{Mineralization}$ and Synthetic Groundwater GR-1

\begin{tabular}{|c|c|c|c|c|}
\hline \multirow[b]{2}{*}{ Radionuclide } & \multicolumn{4}{|c|}{$\mathrm{Kd}, \mathrm{ml} / \mathrm{g}$} \\
\hline & $1 \mathrm{~g} / 10 \mathrm{ml}$ & $1 \mathrm{~g} / 80 \mathrm{ml}$ & $\begin{array}{c}\text { Contact Time, } \\
\text { Days }\end{array}$ & $\begin{array}{c}\text { Tracer } \\
\text { Concentration }\end{array}$ \\
\hline${ }^{75} \mathrm{Se}$ & $3.2 \pm 0.6$ & $18 \pm 3$ & 14 & $\overline{1.74 \times 10^{-12}}$ \\
\hline & 0 & $7 \pm 2$ & 37 & \\
\hline${ }^{85} \mathrm{Sr}$ & $368 \pm 18$ & $881 \pm 35$ & 14 & $1.26 \times 10^{-12}$ \\
\hline & $439 \pm 109$ & $745 \pm 55$ & 37 & \\
\hline${ }^{99} \mathrm{TC}$ & 0 & 0 & 14 & $4.19 \times 10^{-6}$ \\
\hline & 0 & 0 & 37 & \\
\hline${ }^{125} 5_{I}$ & $3.3+0.3$ & $9.8+1.3$ & 14 & $7.24 \times 10^{-13}$ \\
\hline & $3.3 \pm 0.2$ & $20 \pm 3$ & 37 & \\
\hline${ }^{137} \mathrm{Cs}$ & $8,750 \pm 4,860$ & $42,100 \pm 7,000$ & 14 & $1.83 \times 10^{-9}$ \\
\hline & $225,000 \pm 345,000$ & $35,100 \pm 3,300$ & 37 & \\
\hline${ }^{226} \mathrm{Ra}$ & $117 \pm 0.3$ & $553 \pm 12$ & 14 & $1.31 \times 10^{-7}$ \\
\hline & $46 \pm 1$ & $224 \pm 2$ & 37 & \\
\hline${ }^{237} \mathrm{~Np}$ & $12 \pm 2$ & $50 \pm 1$ & 14 & $1.62 \times 10^{-6}$ \\
\hline & $12 \pm 3$ & $49 \pm 6$ & 37 & \\
\hline${ }^{238} U$ & $12 \pm 4$ & $61 \pm 10$ & 14 & $1.01 \times 10^{-6}$ \\
\hline${ }^{241_{A m}}$ & $14,300 \pm 4,300$ & $17,300 \pm 4,000$ & 14 & $2.31 \times 10^{-8}$ \\
\hline & $22,500 \pm 752$ & $76,400 \pm 32,000$ & 37 & \\
\hline${ }^{24} 1_{\mathrm{Pu}}$ & $2,740 \pm 3,100$ & $2,830 \pm 1,800$ & 14 & $1.50 \times 10^{-10}$ \\
\hline & $1,621 \pm 354$ & $9,500 \pm 1,700$ & 37 & \\
\hline
\end{tabular}

slightly with time. The solution in contact with the Pomona basalt tended to increase the most. Very slow reactions between the basalt and solution would have to be the cause of any differences in pH between the blank and the basaltcontaining solutions. The reproducibility of $\mathrm{pH}$ measurements was $\pm 0.1 \mathrm{pH}$ unit. Those experiments in Table 6 that were set aside will be measured in 4 to 8 months.

The dissolved oxygen measurements in the $23^{\circ} \mathrm{C}$ solutions showed little change due to the presence of the basalt at 31 days contact time. The one 
TABLE 9. The $23^{\circ} \mathrm{C}, 1 \mathrm{~g}$ Basalt/10 ml Synthetic Groundwater Solution pH Values at 83 Days of Contact Time. The various blank PH GR-1 values are due to addition of radionuclides in differing chemical media to the solutions.

\begin{tabular}{|c|c|c|c|c|c|}
\hline \multirow[b]{2}{*}{ Radionuclide } & \multicolumn{5}{|c|}{$\mathrm{pH}$} \\
\hline & Blank & $\begin{array}{l}\text { Umtanum } \\
\text { Basalt }\end{array}$ & $\begin{array}{l}\text { Flow } 5 \\
\text { Basalt } \\
\end{array}$ & $\begin{array}{l}\text { Pomona Basalt, } \\
10-20 \text { Mesh } \\
\end{array}$ & $\begin{array}{l}\text { Pomona Basalt, } \\
20-50 \text { Mesh } \\
\end{array}$ \\
\hline${ }^{75} \mathrm{Se}$ & 8.90 & 8.90 & 8.90 & 9.05 & 9.05 \\
\hline${ }^{85} \mathrm{Sr}$ & 7.80 & 8.40 & 8.50 & 8.45 & 8.90 \\
\hline${ }^{99} \mathrm{TC}$ & 9.00 & 9.00 & 9.00 & 9.05 & 9.10 \\
\hline${ }^{125} \mathrm{I}$ & 8.90 & 8.95 & 9.05 & 9.05 & 9.15 \\
\hline${ }^{137} \mathrm{Cs}$ & 8.10 & 8.15 & 8.15 & - & 8.30 \\
\hline${ }^{226} \mathrm{Ra}$ & 7.50 & 7.85 & 8.05 & 8.40 & 8.50 \\
\hline${ }^{237} \mathrm{~Np}$ & 8.05 & 8.50 & 8.50 & 8.65 & 8.80 \\
\hline${ }^{238} U$ & 8.25 & 8.55 & 8.65 & 8.50 & 8.90 \\
\hline${ }^{241}{ }_{A m}$ & 8.00 & 7.90 & 7.95 & - & 8.05 \\
\hline${ }^{24} 1_{\mathrm{Pu}}$ & 7.60 & 7.40 & 7.45 & - & 7.80 \\
\hline
\end{tabular}

TABLE 10. Dissolved Oxygen in the Solution Contacting 0.30 to $0.85-\mathrm{mm}$ Basalt Samples at $23^{\circ} \mathrm{C}$

\begin{tabular}{|c|c|c|c|c|}
\hline \multirow{3}{*}{$\frac{\text { Basalt wt/Solution }}{\text { Volume, } \mathrm{g} / \mathrm{ml}}$} & \multicolumn{4}{|c|}{ Dissolved $0 x y g e n, \mathrm{mg} / 1$ at $23^{\circ} \mathrm{C}$} \\
\hline & \multicolumn{4}{|c|}{16 Days Contact Time } \\
\hline & Blank & Umtanum & Flow E & Pomona \\
\hline $1 / 10$ & 8.25 & 8.00 & 8.30 & 8.20 \\
\hline \multirow[t]{2}{*}{$1 / 80$} & 8.25 & 8.25 & 8.25 & 8.30 \\
\hline & \multicolumn{4}{|c|}{31 Days Contact Time } \\
\hline $1 / 10$ & 8.25 & 8.15 & 8.30 & 8.30 \\
\hline $1 / 80$ & 8.25 & 8.35 & 8.20 & 8.20 \\
\hline
\end{tabular}

exception is the Umtanum basalt. The oxygen measurements are good to within $\pm 2 \%$ of the value given in Table 10 . The dissolved oxygen values at 16 and 21 days contact are not for the same samples. Once an oxygen measurement was made, the sample was discarded. The minor changes in oxygen content indicate that a 11 of the $23^{\circ} \mathrm{C}$ experiments, except those in the controlled atmosphere glovebox, were in an oxidizing environment with the Eh approximately +600 to $700 \mathrm{mv}$. 
$60^{\circ} \mathrm{C}$ STATIC Kd EXPERIMENTS

The $60^{\circ} \mathrm{C}$ experiments were conducted in agitated, controlled air temperature chambers. Temperature control was within $\pm 0.5^{\circ} \mathrm{C}$ of the desired $60^{\circ} \mathrm{C}$. Essentially the same procedure was used as at $23^{\circ} \mathrm{C}$, with the samples and blank solutions at $1 \mathrm{~g}$ solid/10 $\mathrm{ml}$ solution and $1 \mathrm{~g}$ solid/80 $\mathrm{ml}$ solution ratios in polypropylene, 50-ml centrifuge tubes sealed with Teflon tape on the tube cap threads to avoid solution evaporation. Pipette tips were stored in the chamber along with the samples at $60^{\circ} \mathrm{C}$ to ensure that the same volume was pipetted each time for counting. A set of six samples ( 3 blank solutions +3 solidssolution samples) was removed from the chamber and aliquots rapidly taken to avoid sample cooling. Temperature changes result in concomitant volume changes in the solution, in turn causing counting errors affecting $K d^{\prime}$ results.

Initial results of the $60^{\circ} \mathrm{C} \mathrm{Kd'} \mathrm{determinations} \mathrm{are} \mathrm{shown} \mathrm{in} \mathrm{Tables} 11,12$ and 13. Elapsed solution-solid contact times are not adequately long in many cases to allow any firm conclusions. However, it appears that selenium, technetium, iodine, neptunium and probably uranium $K d^{\prime}$ 'values will remain as low as they were at $23^{\circ} \mathrm{C}$. There is some evidence for an increase of strontium and radium Kd' with a temperature increase, and a decrease in cesium Kd' with a temperature increase. The decrease in cesium $K d^{\prime}$ may be due to an increase in contacting solution ionic strength, while the strontium and radium Kd' increase may be due to the formation of secondary mineral phases at higher temperatures that remove strontium and radium from solution. Only two Kd' values are available for each radionuclide with the secondary mineralization. However, these tend to be higher than the basalts for the simple cations strontium and cesium, probably because of the high cation exchange capacity and surface area of the smectite clay that is the main mineral constituent of the secondary mineralization.

\section{$150^{\circ} \mathrm{C}$ STATIC Kd EXPERIMENTS}

The $150^{\circ} \mathrm{C}$ experiments were performed in $300-\mathrm{ml}$-capacity Incone 1600 pressure vessels. Purified argon was used to sparge dissolved oxygen from the solution and atmosphere above it before pressurization with Ar. Thus, the solution and basalt sample were low in oxygen and $\mathrm{CO}_{2}$ content before the 
TABLE 11. The $60^{\circ} \mathrm{C} \mathrm{Kd}$ 'values for $0.30-$ to $0.85-\mathrm{mm}$ Basalts and Synthetic Groundwater GR-1 at $1 \mathrm{~g}$ Basalt/10 ml Solution

\begin{tabular}{|c|c|c|c|c|c|}
\hline \multirow[b]{2}{*}{ Radionuclide } & \multicolumn{4}{|c|}{$\mathrm{Kd}, \mathrm{ml} / \mathrm{g}$} & \multirow[b]{2}{*}{$\begin{array}{c}\text { Radionuclide } \\
\text { Initial Conc., M }\end{array}$} \\
\hline & $\begin{array}{l}\text { Umtanum } \\
\text { Basalt }\end{array}$ & $\begin{array}{l}\text { Flow E } \\
\text { Basalt } \\
\end{array}$ & $\begin{array}{l}\text { Pomona } \\
\text { Basalt }\end{array}$ & $\begin{array}{l}\text { Contact } \\
\text { Time, Days } \\
\end{array}$ & \\
\hline \multirow{3}{*}{${ }^{75} \mathrm{Se}$} & $9 \pm 1$ & $4 \pm 0.1$ & $2 \pm 0.4$ & 11 & $1.08 \times 10^{-12}$ \\
\hline & $10 \pm 0.3$ & $7 \pm 1$ & $2 \pm 0.3$ & 36 & \\
\hline & $10 \pm 0.8$ & $7 \pm 0.8$ & $4 \pm 0.2$ & 59 & \\
\hline \multirow[t]{3}{*}{${ }^{85} \mathrm{Sr}$} & $82 \pm 10$ & $58 \pm 1$ & $82 \pm 11$ & 11 & $5.74 \times 10^{-13}$ \\
\hline & $178 \pm 22$ & $130 \pm 10$ & $156 \pm 43$ & 36 & \\
\hline & $237 \pm 37$ & $171 \pm 20$ & $225 \pm 58$ & 59 & \\
\hline \multirow[t]{3}{*}{${ }^{99} \mathrm{TC}$} & $39 \pm 15$ & $0.7 \pm 0.5$ & $\overline{0}$ & 11 & $4.32 \times 10^{-6}$ \\
\hline & $35 \pm 20$ & 0 & 0 & 36 & \\
\hline & $36 \pm 26$ & 0 & 0 & 59 & \\
\hline \multirow[t]{3}{*}{${ }^{125} \mathrm{I}$} & $\overrightarrow{0}$ & 0 & 0 & 11 & $4.35 \times 10^{-13}$ \\
\hline & 0 & 0 & 0 & 36 & \\
\hline & 0 & 0 & 0 & 59 & \\
\hline \multirow[t]{3}{*}{${ }^{137} \mathrm{Cs}$} & $209 \pm 5$ & $122 \pm 3$ & $294 \pm 7$ & 11 & $2.28 \times 10^{-9}$ \\
\hline & $468 \pm 82$ & $221 \pm 9$ & $652 \pm 29$ & 36 & \\
\hline & $550 \pm 49$ & $251 \pm 16$ & $938 \pm 71$ & 59 & \\
\hline \multirow[t]{3}{*}{${ }^{226} \mathrm{Ra}_{\mathrm{a}}$} & $125 \pm 23$ & $110 \pm 12$ & $147 \pm 40$ & 11 & $1.21 \times 10^{-1}$ \\
\hline & $57 \pm 1$ & $51 \pm 6$ & $59 \pm 0.2$ & 36 & \\
\hline & $66 \pm 6$ & $53 \pm 3$ & $67 \pm 3$ & 59 & \\
\hline \multirow[t]{3}{*}{${ }^{237} \mathrm{~Np}$} & $9 \pm 1$ & $3 \pm 3$ & $10 \pm 9$ & 11 & $1.62 \times 10^{-6}$ \\
\hline & $16 \pm 4$ & $6 \pm 1$ & $7 \pm 1$ & 36 & \\
\hline & $13 \pm 1$ & $6 \pm 1$ & $6 \pm 1$ & 59 & \\
\hline \multirow{4}{*}{$\begin{array}{l}{ }^{238} \mathrm{U} \\
241_{A m}\end{array}$} & $69 \pm 54$ & $17 \pm 11$ & $17 \pm 12$ & 36 & $1.01 \times 10^{-6}$ \\
\hline & $126 \pm 29$ & $103 \pm 33$ & $56 \pm 15$ & 11 & $1.50 \times 10^{-8}$ \\
\hline & $35 \pm 2$ & $48 \pm 42$ & $63 \pm 39$ & 36 & \\
\hline & $69 \pm 22$ & $84 \pm 47$ & $235 \pm 187$ & 59 & \\
\hline \multirow[t]{3}{*}{${ }^{241} P_{u}$} & $118 \pm 75$ & $68 \pm 25$ & $52 \pm 17$ & 11 & $6.65 \times 10^{-11}$ \\
\hline & $187 \pm 76$ & $229 \pm 18$ & $139 \pm 45$ & 36 & \\
\hline & $282 \pm 108$ & $565 \pm 489$ & $646 \pm 108$ & 59 & \\
\hline
\end{tabular}




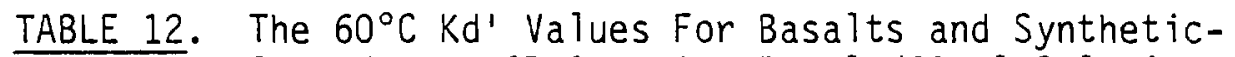
Groundwater GR-1 at $1 \mathrm{~g}$ Basalt/80 ml Solution

\begin{tabular}{|c|c|c|c|c|c|}
\hline \multirow[b]{2}{*}{ Radionuclide } & \multicolumn{4}{|c|}{$\mathrm{Kd} \mathrm{d}^{\prime}, \mathrm{ml} / \mathrm{g}$} & \multirow[b]{2}{*}{$\begin{array}{l}\text { Radionuclide } \\
\text { Conc., M } \\
\end{array}$} \\
\hline & $\begin{array}{l}\text { Umtanum } \\
\text { Basalt }\end{array}$ & $\begin{array}{l}\text { Flow E } \\
\text { Basalt } \\
\end{array}$ & $\begin{array}{l}\text { Pomona } \\
\text { Basalt } \\
\end{array}$ & $\begin{array}{l}\text { Contact } \\
\text { Time } \\
\text { Days } \\
\end{array}$ & \\
\hline \multirow[t]{3}{*}{${ }^{75} \mathrm{Se}$} & $14 \pm 4$ & $14 \pm 3$ & $2 \pm 1$ & 11 & $1.66 \times 10^{-6}$ \\
\hline & $17 \pm 7$ & $20 \pm 5$ & $7 \pm 5$ & 36 & \\
\hline & $23 \pm 3$ & $26 \pm 3$ & $10 \pm 4$ & 59 & \\
\hline \multirow[t]{3}{*}{${ }^{85} \mathrm{Sr}$} & $126 \pm 17$ & $91 \pm 3$ & $158 \pm 12$ & 11 & $9.93 \times 10^{-13}$ \\
\hline & $164 \pm 43$ & $102 \pm 5$ & $176 \pm 15$ & 36 & \\
\hline & $173 \pm 22$ & $102 \pm 5$ & $161 \pm 10$ & 59 & \\
\hline \multirow[t]{3}{*}{${ }^{99} \mathrm{TC}$} & $7 \pm 5$ & 0 & 0 & 11 & $1.02 \times 10^{-5}$ \\
\hline & $10 \pm 7$ & 0 & 0 & 36 & \\
\hline & $9 \pm 6$ & 0 & 0 & 59 & \\
\hline \multirow[t]{3}{*}{${ }^{125} \mathrm{I}$} & 0 & 0 & 0 & 11 & $7.66 \times 10^{-13}$ \\
\hline & 0 & 0 & 0 & 36 & \\
\hline & 0 & 0 & 0 & 59 & \\
\hline \multirow[t]{3}{*}{${ }^{137} \mathrm{Cs}$} & $447 \pm 30$ & $153 \pm 14$ & $528 \pm 28$ & 11 & $3.72 \times 10^{-9}$ \\
\hline & $669 \pm 48$ & $171 \pm 19$ & $759 \pm 60$ & 36 & \\
\hline & $712 \pm 32$ & $175 \pm 21$ & $792 \pm 25$ & 59 & \\
\hline \multirow[t]{3}{*}{${ }^{226} 6_{\mathrm{Ra}}$} & $348 \pm 41$ & $310 \pm 71$ & $656 \pm 201$ & 11 & $2.90 \times 10^{-7}$ \\
\hline & $310 \pm 43$ & $210 \pm 23$ & $243 \pm 10$ & 36 & \\
\hline & $323 \pm 36$ & $232 \pm 29$ & $277 \pm 20$ & 59 & \\
\hline \multirow[t]{3}{*}{${ }^{237} \mathrm{~Np}$} & $24 \pm 8$ & $15 \pm 5$ & $17 \pm 1$ & 11 & $2.69 \times 10^{-6}$ \\
\hline & $37 \pm 4$ & $27 \pm 0$ & $25 \pm 3$ & 36 & \\
\hline & $38 \pm 4$ & 0 & $14 \pm 6$ & 59 & \\
\hline $238_{U}$ & $\overline{0}$ & 0 & $\overline{0}$ & 36 & $1.86 \times 10^{-6}$ \\
\hline \multirow[t]{3}{*}{${ }^{241}{ }_{A m}$} & $5,621 \pm 2,272$ & $3,609 \pm 99$ & $2,361 \pm 376$ & 11 & $3.81 \times 10^{-8}$ \\
\hline & $11,587 \pm 470$ & $775 \pm 395$ & $566 \pm 52$ & 36 & \\
\hline & $429 \pm 179$ & $293 \pm 134$ & $247 \pm 156$ & 59 & \\
\hline \multirow[t]{3}{*}{$241_{P u}$} & $1,174 \pm 128$ & $580 \pm 80$ & $812 \pm 211$ & 11 & $1.10 \times 10^{-10}$ \\
\hline & $1,596 \pm 698$ & $593 \pm 93$ & $473 \pm 173$ & 36 & \\
\hline & $1,322 \pm 467$ & $636 \pm 38$ & $483 \pm 159$ & 59 & \\
\hline
\end{tabular}


TABLE 13. The $60^{\circ} \mathrm{C} \mathrm{Kd'} \mathrm{Values} \mathrm{for} \mathrm{Secondary} \mathrm{Mineralization} \mathrm{and} \mathrm{Synthetic}$ Groundwater GR-1. Initial radionuclide concentrations are the same as those given in Table 12.

\begin{tabular}{|c|c|c|c|}
\hline \multirow[b]{2}{*}{ Radionuclide } & \multicolumn{3}{|c|}{$\mathrm{Kd} \mathrm{d}^{\prime}, \mathrm{ml} / \mathrm{g}$} \\
\hline & $1 \mathrm{~g} / 10 \mathrm{ml}$ & $1 \mathrm{~g} / 80 \mathrm{ml}$ & $\begin{array}{c}\text { Contact } \\
\text { Time, Days } \\
\end{array}$ \\
\hline${ }^{75} \mathrm{Se}$ & $1.1 \pm 0.8$ & $7.1 \pm 4.7$ & 14 \\
\hline & 0 & $4.2 \pm 3.9$ & 37 \\
\hline${ }^{85} \mathrm{Sr}$ & $772 \pm 580$ & $906 \pm 46$ & 14 \\
\hline & $499 \pm 167$ & $997 \pm 14$ & 37 \\
\hline${ }^{99} \mathrm{TC}$ & 0 & $\overline{0}$ & 14 \\
\hline & 0 & 0 & 37 \\
\hline${ }^{125} \mathrm{I}$ & 0 & 0 & 14 \\
\hline & 0 & 0 & 37 \\
\hline${ }^{137} \mathrm{Cs}$ & $22,200 \pm 18,500$ & $15,300 \pm 4,300$ & 14 \\
\hline & $1,701 \pm 1,099$ & $17,000 \pm 1,000$ & 37 \\
\hline${ }^{226}{ }_{\mathrm{Ra}}$ & $212 \pm 17$ & $1,220 \pm 180$ & 14 \\
\hline & $90 \pm 7$ & $613 \pm 79$ & 37 \\
\hline${ }^{237} \mathrm{~Np}$ & $14 \pm 2$ & $63 \pm 5$ & 14 \\
\hline & $17 \pm 4$ & $66 \pm 21$ & 37 \\
\hline $238 U$ & $25 \pm 13$ & $349 \pm 79$ & 14 \\
\hline${ }^{241} \mathrm{Am}$ & $4,700 \pm 2,500$ & $16,200 \pm 1,400$ & 14 \\
\hline & $7,275 \pm 3,100$ & $20,000 \pm 7,400$ & 37 \\
\hline${ }^{241} \mathrm{Pu}$ & $767 \pm 228$ & $2,200 \pm 1,144$ & 14 \\
\hline & $1,536 \pm 750$ & $611 \pm 270$ & 37 \\
\hline
\end{tabular}

experiments began. Temperatures and pressure were continuously recorded to ensure that pressure vessel operation was uninterrupted during the experiment duration. Samples were taken, via a 1/8-in. Inconel sample line that extended below the liquid level in the vessel, at the vessel operating temperature and pressure. The part of the sample line exterior to the vessel was cooled to collect a liquid sample. A few $\mathrm{ml}$ of solution were passed through the sample line each time to flush the line and avoid contamination of the sample with 
the portion of the last sample remaining in the sample tubing. All of the samples taken for counting were pipetted at the same temperature to obtain equal sample volumes.

The vessels were lined with machined Teflon to hold vessel wall adsorption to a minimum. A comparison between $\mathrm{Kd}^{\prime}$ values due to vessel wall adsorption with lined and unlined vessels is shown in Table 14. No basalt was present. A solution sample taken before the vessels were presurized and heated was used for the original solution radionuclide solution count. Strontium, cesium, iodine, and selenium showed reduced $K d^{\prime}$ 'values indicating reduced wall adsorption, while lining apparently has little effect on plutonium adsorption. Much of the remaining adsorption may be due to the low ionic strength of the blank solution and adsorption on sample line tubing.

When a basalt is added to the solution, plutonium adsorption is considerably lowered as seen in Table 15. Plutonium Kd' values with the Teflon liner have not been completed. Iodine, on the other hand, increased considerably in Kd' in the Teflon lined vessel, which indicate that an iodine reaction with the Teflon liner occurs in the lined vessel. Strontium and plutonium increase together suggesting that growth of a new mineral phase may be removing both of these elements. Cesium changes little between the lined and unlined vessels as shown in Figure 5 . 
TABLE 14. Measured Blank Solution $K d^{\prime}$ Values at $150^{\circ} \mathrm{C}$ and $6.9 \mathrm{MPa}$ Ar with and Without a Teflon Liner Present in the Pressure Vessels. The initial radionuclide concentrations were the same as those at $23^{\circ} \mathrm{C}$ and $1 \mathrm{~g}$ basalt/10 $\mathrm{ml}$ solution.

\begin{tabular}{|c|c|c|c|c|c|}
\hline \multirow[b]{2}{*}{ Contact Time, Days } & \multicolumn{5}{|c|}{$\mathrm{Kd}, \mathrm{ml} / \mathrm{g}$, No Teflon Liner } \\
\hline & ${ }^{85} s r$ & ${ }^{137} \mathrm{Cs}$ & $125_{I}$ & ${ }^{75} \mathrm{Se}$ & ${ }^{237} \mathrm{Pu}$ \\
\hline 1.0 & 6.9 & 1.0 & $\sim_{0}$ & 2.4 & $>10,000$ \\
\hline 2.0 & 7.0 & 0.8 & $\sim 0$ & 9.6 & $>10,000$ \\
\hline 3.0 & 6.5 & 1.7 & $\sim 0$ & 195.0 & $>10,000$ \\
\hline \multirow[t]{2}{*}{7.0} & 7.9 & 1.5 & $\sim 0$ & $>10,000$ & $>10,000$ \\
\hline & \multicolumn{5}{|c|}{ Kd', $\mathrm{m} 1 / \mathrm{g}$, Teflon Liner } \\
\hline 1.1 & 8.0 & $\sim 0$ & $\sim 0$ & $\sim 0$ & $>10,000$ \\
\hline 4.1 & 3.5 & $\sim 0$ & $\sim 0$ & 159 & $>10,000$ \\
\hline 6.1 & 0.7 & $\sim 0$ & $\sim 0$ & 72 & $>10,000$ \\
\hline
\end{tabular}

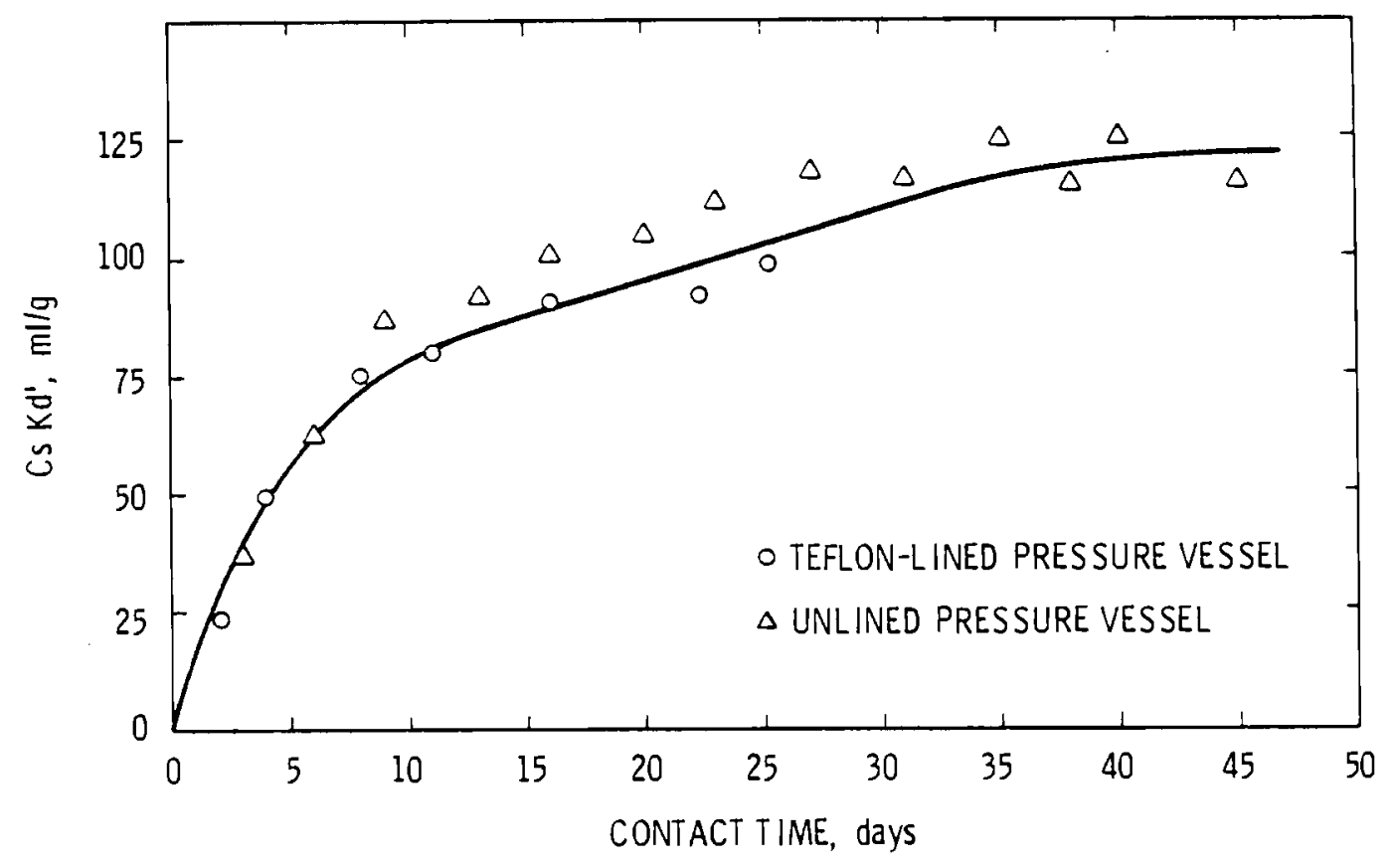

FIGURE 5. Cesium Kd' Value Versus Contact Time in Days for Umtanum Basalt at $150^{\circ} \mathrm{C}$ and $6.9 \mathrm{MPa} \mathrm{Ar}, 1 \mathrm{~g} \mathrm{Basalt} / 10 \mathrm{ml}$ of Synthetic Groundwater 
TABLE 15. Radionuclide Kd' Values Obtained With 0.30 to 0.85 -mm Umtanum Basalt at $150^{\circ} \mathrm{C}$ and $6.9 \mathrm{MPa} \mathrm{Ar}, 1 \mathrm{~g}$ Basalt/10 ml Solution. Initial radionuclide concentrations are the same as those given for $1 \mathrm{~g} / 10 \mathrm{ml}$ and $23^{\circ} \mathrm{C}$.

\begin{tabular}{|c|c|c|c|c|c|}
\hline \multirow[b]{2}{*}{ Contact Time, Days } & \multicolumn{5}{|c|}{$\mathrm{Kd}, \mathrm{ml} / \mathrm{g}$, No Teflon Liner } \\
\hline & ${ }^{85} \mathrm{sr}$ & ${ }^{137} \mathrm{Cs}$ & $125 I$ & ${ }^{75} \mathrm{Se}$ & ${ }^{237} \mathrm{Pu}$ \\
\hline 3.0 & 54 & 37 & 0.8 & 120 & 88 \\
\hline 6.1 & 72 & 63 & 0.1 & 106 & 68 \\
\hline 9.1 & 85 & 87 & 0.2 & 122 & 115 \\
\hline 13.1 & 88 & 92 & 0.5 & 105 & 168 \\
\hline 16.2 & 91 & 101 & 0.8 & 126 & 195 \\
\hline 20.0 & 92 & 105 & 0.4 & 136 & 189 \\
\hline 24.6 & 922 & 112 & $\sim 0$ & 119 & 123 \\
\hline 28.6 & 896 & 118 & 0.1 & 86 & 123 \\
\hline 32.5 & 393 & 117 & 0.2 & 125 & 370 \\
\hline 36.6 & 3613 & 124 & $\sim 0$ & 155 & $>10,000$ \\
\hline 39.6 & $>10,000$ & 116 & 0.3 & 158 & $>10,000$ \\
\hline 42.6 & $>10,000$ & 125 & 0.7 & 166 & $>10,000$ \\
\hline 45.6 & $>10,000$ & 116 & 0.3 & 360 & $>10,000$ \\
\hline
\end{tabular}

$\begin{array}{rcrrrr}2.0 & 212 & 23 & 9 & 19 & - \\ 3.9 & 4423 & 49 & 16 & 33 & - \\ 7.9 & >10,000 & 75 & 16 & 100 & - \\ 11.0 & 251 & 80 & 21 & 311 & - \\ 16.0 & 1468 & 91 & 20 & 95 & - \\ 22.3 & 232 & 92 & 16 & 126 & - \\ 25.2 & 340 & 98 & 12 & 75 & - \\ 30.2 & 536 & 102 & 20 & 82 & - \\ 36.2 & 946 & 101 & 20 & 85 & - \\ 39.2 & 406 & 92 & 20 & 73 & - \\ 46.2 & >10,000 & 97 & 20 & 105 & -\end{array}$




\section{REFERENCES}

Deju, R. A., R. K. Ledgerwood, and P. E. Long. 1978. Reference Waste Form, Basalts, and Groundwater Systems for Waste Interaction Studies. RHO-BWI-LD-11. Rockwe11 Hanford Operations, Richland, WA.

Eber 1, D., G. Whitney and H. Khoury. 1978. "Hydrothermal Reactivity of Smectite." Amer. Mineral. 63:401-409.

Eichholz, G. G., T. F. Craft and A. N. Galli. 1967. "Trace Element Fractionation by Suspended Matter in Water." Geochim. et Cosmochim. Acta. 31: $737-745$.

Hodge, C. E. and M. W. Grutzeck. 1978. Preparation of Standard Umtanum Sample by Battel le Northwest Laboratories. RHO-BWI-LD-3, RockwelT Hanford Operations, Richland, WA.

Rai, D. and W. T. Franklin. 1978. "Effect of Moisture Content on Ethylene Glycol Retention by Clay Minerals." Geoderma. 21:75-79.

Sillen, L. G. 1971. Stability Constants of Metal-Ion Complexes. Supplement No. 1, Part 1. Inorganic Ligands. Spec. Publ. No. 25. The Chemical Society, London. 22.

van 0lphen, H. 1965. "Collapse of Potassium Montmorillonite Clays Upon Heating - Potassium Fixation." Clays and Clay Minerals, Proc. 14th National Conf. Berkeley, CA. Pergamon Press, London. 393-405.

Weaver, C. E. 1958. "The Effects and Geologic Significance of Potassium "Fixation" by Expandable Clay Minerals Derived from Muscovite, Chlorite and Volcanic Material." Amer. Mineral. 43:839-861. 
APPENDIX A

CHARACTERIZATION OF FLOW E AND POMONA BASALTS 


\section{APPENDIX A}

CHARACTERIZATION OF FLOW E BASALT

(Ames 1978)

\begin{tabular}{|c|c|c|}
\hline Constituent & \multicolumn{2}{|c|}{ Wt. \% } \\
\hline $\mathrm{SiO}_{2}$ & 53.96 & 54.02 \\
\hline $\mathrm{Al}_{2} \mathrm{O}_{3}$ & 13.89 & 13.89 \\
\hline $\mathrm{TiO}_{2}$ & 1.94 & 1.95 \\
\hline $\mathrm{FeO}$ & 12.27 & 12.29 \\
\hline $\mathrm{MnO}$ & 0.20 & 0.20 \\
\hline $\mathrm{CaO}$ & 8.46 & 8.39 \\
\hline $\mathrm{MgO}$ & 4.33 & 4.37 \\
\hline $\mathrm{K}_{2} \mathrm{O}$ & 1.20 & 1.19 \\
\hline $\mathrm{Na}_{2} \mathrm{O}$ & 3.43 & 3.39 \\
\hline $\mathrm{P}_{2} \mathrm{O}_{5}$ & 0.32 & 0.31 \\
\hline Total & $100.00 *$ & 100.00 \\
\hline
\end{tabular}

*Analyses total $100 \%$ due to normalization of the $X$-ray fluorescence data by a computer program.

Major Mineral Phases Found by X-Ray Diffraction

Feldspar, Clinopyroxene

Microprobe Chemical Analyses and Computed Mineral Compositions

\begin{tabular}{|c|c|c|c|c|c|c|c|c|c|c|c|c|c|}
\hline & \multicolumn{13}{|c|}{ wt. \% } \\
\hline & 1 & 2 & 3 & 4 & 5 & 6 & 7 & 8 & 9 & 10 & 11 & 12 & 13 \\
\hline $\mathrm{iO}_{2}$ & 60.5 & 58.7 & 49.4 & 52.6 & 46.9 & 51.8 & 36.4 & 0.2 & 0.2 & 0.3 & 55.3 & 76.3 & 76.9 \\
\hline $1 \overline{0}_{3}$ & 24.4 & 26.1 & 0.8 & 1.1 & 1.0 & 0.9 & -. & 0.2 & 0.9 & 2.2 & 6.3 & 12.9 & 11.6 \\
\hline $\mathrm{TiO}_{2}$ & -- & - & 0.6 & 0.4 & 0.6 & 0.4 & -- & 51.8 & 27.9 & 28.1 & 0.1 & 0.7 & -. \\
\hline 0 & 0.9 & 0.8 & 21.6 & 11.5 & 17.0 & 29.8 & 52.0 & 45.5 & 68.8 & 68.4 & 27.6 & 1.9 & 1.4 \\
\hline no & -- & -- & 0.4 & 0.2 & 0.2 & 0.5 & 0.7 & 0.4 & 0.3 & 0.4 & -- & -- & -- \\
\hline 20 & 9.3 & 11.9 & 11.9 & 19.1 & 20.2 & 8.2 & 0.4 & -- & -- & -- & 1.3 & 0.5 & 0.4 \\
\hline 190 & -- & -- & 12.1 & 15.1 & 11.3 & 8.3 & 12.1 & -- & 0.5 & 1.4 & 5.0 & -- & -. \\
\hline 20 & 0.9 & 0.5 & -- & -- & -- & -- & -- & - & -- & -- & 0.6 & 6.9 & 6.5 \\
\hline $\mathrm{la}_{2} 0$ & 5.8 & 4.7 & -- & -. & -- & -- & -- & -- & -- & -- & -- & -. & $\cdots$ \\
\hline${ }_{2} \mathrm{O}_{5}$ & -- & -- & - & -- & -- & -- & - & - & -- & -- & - & -- & -- \\
\hline OTAL & 101.3 & 102.7 & 96.8 & 100.0 & 97.2 & 99.9 & 101.6 & 98.1 & 98.6 & 100.8 & 96.2 & 99.2 & 96.3 \\
\hline
\end{tabular}


1. $\left(\mathrm{Na}_{1.99}, \mathrm{Ca}_{1.77}, \mathrm{~K}_{0.20}\right)\left(\mathrm{Al}_{5.11}, \mathrm{Si}_{10.74}\right) \mathrm{O}_{32}$

2. $\left(\mathrm{Na}_{1.62}, \mathrm{Ca}_{2.26}, \mathrm{~K}_{0.12}\right)\left(\mathrm{Al}_{5.45}, \mathrm{Si}_{10.40}\right) \mathrm{O}_{32}$

3. $\left(\mathrm{Mg}_{0.72}, \mathrm{Fe}_{0.72}, \mathrm{Ca}_{0.51}, \mathrm{Ti}_{0.02}, \mathrm{Mn}_{0.01}, \mathrm{Al}_{0.03}\right.$

$\left(\mathrm{Al}_{0.03}, \mathrm{Si}_{1.97}\right)_{6}$

4. $\left(\mathrm{Mg}_{0.84}, \mathrm{Fe}_{0.36}, \mathrm{Ca}_{0.77}, \mathrm{Ti}_{0.01}, \mathrm{Mn}_{0.01}, \mathrm{Al}_{0.02}\right)$

$\left(\mathrm{Al}_{0.03}, \mathrm{Si}_{1.97}\right)_{6}$

5. $\left(\mathrm{Mg}_{0.68}, \mathrm{Fe}_{0.57}, \mathrm{Ca}_{0.87}, \mathrm{Ti}_{0.02}, \mathrm{Mn}_{0.01}\right)$

$\mathrm{Al}_{0.05},\left(\mathrm{Si}_{1.88}\right)_{6} \mathrm{O}_{6}$

6. $\left(\mathrm{Mg}_{0.47}, \mathrm{Fe}_{0.95}, \mathrm{Ca}_{0.33}, \mathrm{Ti}_{0.01}, \mathrm{Mn}_{0.02}, \mathrm{Al}_{0.04}\right)$

$\left(\mathrm{Si}_{1.96}\right) \mathrm{O}_{6}$

7. -.-

8. $(\mathrm{Fe}, \mathrm{Mn})_{1.98}(\mathrm{Ti})_{2.006}$

9. ---

10. - -.-

11. $\left(\mathrm{Al}_{0.15},{ }^{\mathrm{Mg}} 0.49, \mathrm{Fe}_{1.53}\right)\left(\mathrm{Al}_{0.34}, \mathrm{Si}_{3.66}\right) \mathrm{O}_{10}(\mathrm{OH})_{2}$

12. Ground mass

13. Ground mass

Note: The dashes indicate that constituent was below detection limits.

Ethylene Giycol Sorption Surface Area, 20 to 50 Mesh

$10.3 \pm 1.0 \mathrm{~m}^{2} / \mathrm{g}$

Strontium Cation Exchange Capacity, 20 to 50 Mesh

$4.7 \pm 0.2 \mathrm{meq} / 100 \mathrm{~g}$ 
Estimation of Quantitative Mineralogy on the Quantimet (electronic point counting)

\begin{tabular}{|c|c|}
\hline Major Minerals & Wt. \% \\
\hline Plagioclase $\left(\mathrm{Ab}_{55}-\mathrm{Ab}_{40}\right)$ & 44 \\
\hline Clinopyroxenes & 32 \\
\hline Groundmass (including glass) & 13 \\
\hline Metallic Oxides & 6 \\
\hline Clays & 5 \\
\hline
\end{tabular}




\section{CHARACTERIZATION OF POMONA BASALT}

(Deju et al. 1978)

Whole Rock Chemical Analyses

Constituent

Wt. \%

$\begin{array}{lrrrrrr}\mathrm{SiO}_{2} & 52.98 & 51.87 & 52.39 & 52.01 & 52.78 & 52.04 \\ \mathrm{Al}_{2} \mathrm{O}_{3} & 15.63 & 15.02 & 14.92 & 14.88 & 15.50 & 15.11 \\ \mathrm{TiO}_{2} & 1.58 & 1.55 & 1.58 & 1.55 & 1.60 & 1.61 \\ \mathrm{Fe}_{2} \mathrm{O}_{3} & 2.00 & 2.00 & 2.00 & 2.00 & 2.00 & 2.00 \\ \mathrm{FeO}^{2} & 8.99 & 8.89 & 8.21 & 8.99 & 8.90 & 8.95 \\ \mathrm{MnO} & 0.19 & 0.19 & 0.18 & 0.19 & 0.19 & 0.20 \\ \mathrm{CaO} & 8.89 & 10.58 & 10.94 & 10.62 & 8.73 & 10.44 \\ \mathrm{MgO} & 6.79 & 7.08 & 6.94 & 7.17 & 7.22 & 6.97 \\ \mathrm{~K}_{2} \mathrm{O} & 0.65 & 0.39 & 0.53 & 0.35 & 0.53 & 0.34 \\ \mathrm{Na}_{2} \mathrm{O} & 2.07 & 2.23 & 2.09 & 2.02 & 2.24 & 2.22 \\ \mathrm{P}_{2} \mathrm{O}_{5} & 0.25 & 0.19 & 0.22 & 0.21 & 0.31 & 0.23\end{array}$

Major Mineral Phases Found by X-Ray Diffraction

Feldspar, Clinopyroxene

Ethylene Glycol Sorption Surface Areas

$$
\frac{0.85-0.30 \mathrm{~mm}}{31.2 \pm 1.4 \mathrm{~m}^{2} / \mathrm{g}} \quad \frac{2.00-0.85 \mathrm{~mm}}{27.4 \pm 0.7 \mathrm{~m}^{2} / \mathrm{g}}
$$

Estimate of Quantitative Mineralogy by Point Counting

\begin{tabular}{lrr}
\multicolumn{1}{c}{ Major Minerals } & Volume $\%$ \\
\cline { 1 - 1 } Plagioclase, laboradorite to andesine & 33.9 to 28.7 \\
Pyroxene, mainly augite & 37.2 to 30.8 \\
Olivine & 2.8 to 1.4 \\
Metallic 0xides & 5.5 to 2.8
\end{tabular}

Other Phases

Tachylyte (nearly anhydrous basaltic glass) 34.5 to 17.1

Opal 3.5 to 1.8 
APPENDIX B

CHARACTERIZATION OF SECONDARY MINERALIZATION 
APPENDIX B

\section{CHARACTERIZATION OF SECONDARY MINERALIZATION}

\section{SAMPLE TREATMENT}

During excavation of the Near-Surface Test Facility on the Hanford Site, about $10 \mathrm{~kg}$ of Pomona basalt secondary mineralization was recovered and stored in plastic bags to avoid loss of water. The larger chunks of fracture mineralization showed dark green exterior surfaces and light blue centers. These characteristics suggest that oxidation had been occurring since exposure to the atmosphere. Nontronite normally is green in color, but contains ferric iron $\left(\mathrm{Fe}^{3+}\right)$ as a part of its structure. The ferric iron is already fully oxidized so that the nontronite color is stable. The color change of the secondary mineralization may be due to admixed ferrous or manganous ioncontaining materials.

Distilled water was added to the as-received secondary mineralization sample, and a blender used to physically disperse the sample to an overal1 mayonnaise consistency. Of the $10 \mathrm{~kg}$ total weight, $1.2 \mathrm{~kg}$ were admixed Pomona basalt fragments of various dimensions. The large basalt fragments were removed before blending or later by forcing the sample through a 50-mesh stainless stee 1 screen. Approximately $20 \mathrm{l}$ of basalt-free fracture mineralization were finally obtained, homogenized by stirring in a large vessel and placed in $1-\ell$ polyethylene containers. The filled containers were frozen at minus $20^{\circ} \mathrm{C}$. The frozen containers were dried under vacuum to produce a freezedried product. This treatment method in preparation for use of the fracture mineralization in $\mathrm{Kd}^{\prime}$ determination work caused the least damage to any of the smectite clays present in the sample (van 0lphen 1965).

After freeze-drying, the various fractions were remixed into a single sample and placed in a dessicator so that the same amount of sample containing the same amount of water could be weighed out each time the secondary mineralization was used. 


\section{X-RAY DIFFRACTION RESULTS}

Tracings of the as-received and potassium-based secondary mineralization $\mathrm{Cu} K \alpha, x$-ray diffraction patterns are shown in Figure B.1. The air-dried, as-received material, taken from the homogenous clay after dispersion and before freezing, is shown in curve a of Figure B.1. A large basal peak at $5.5^{\circ} 2 \theta$ is the main feature. No kaolinite, chlorite, illite, vermiculite or mica are present. Vapor glycolation of the as-received sample at $60^{\circ} \mathrm{C}$ resulted in a normal $17 \mathrm{~A}$ smectite or expanding layer silicate as shown in curve b. Potassium basing with gentle heating results in collapse of nontronite-beidellite mixtures to a $10 \AA$ mica spacing (van 0lphen 1965), as seen in curve $c$ of Figure B.1. The low temperature collapse is caused by the large percentage of lattice charge due to substitution in the tetrahedral layer and the presence of potassium on exchangeable cation positions (Weaver 1958).

\section{CHEMICAL COMPOSITION}

The chemical composition of the as-received secondary mineralization is given in Table B.1. An average of $25 \mathrm{wt} . \%$ water was contained in the analyzed samples. Six fragments of secondary mineralization were selected at random from the original material for mounting and electron microprobe chemical analysis.

Note that these analyses are relatively uniform, which suggests that the secondary mineralization is also relatively uniform in chemical composition. No attempts were made to determine a mineral formula from these analyses because the observed change in clay color from light blue to dark green upon exposure to the atmosphere strongly suggests an admixed phase or phases. Such an admixed material would be very difficult to quantify. In addition, up to 4 wt.\% of the magnesium could be present as exchangeable cations rather than occupying an octahedral structural position. Further study of the clay would be required (exchangeable cations, etc.) before a probable formula could be derived. 


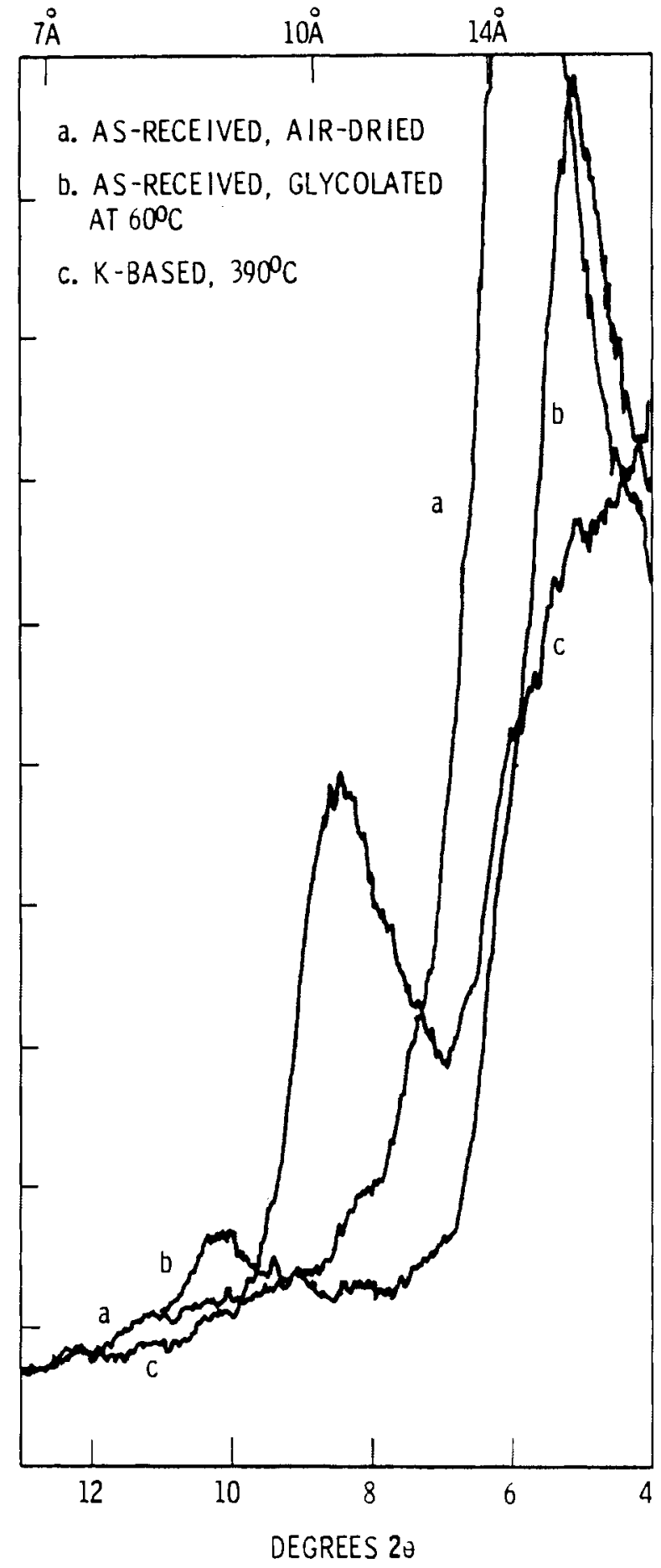

FIGURE B.1. X-Ray Diffraction Patterns of Treated and Untreated Secondary Mineralization

B. 3 
TABLE B.1. The As-Received Chemical Composition of the Secondary Mineralization Used in the Radionuclide Distribution Determinations. The remainder of the total $\mathrm{wt} \%$ was water.

\begin{tabular}{|c|c|c|c|c|c|c|}
\hline Constituent & \multicolumn{6}{|c|}{ Wt. \% } \\
\hline $\mathrm{SiO}_{2}$ & 43.2 & 45.5 & 44.5 & 44.3 & 45.3 & 43.2 \\
\hline $\mathrm{Al}_{2} \mathrm{O}_{3}$ & 6.5 & 6.6 & 6.6 & 6.5 & 6.9 & 6.4 \\
\hline $\mathrm{TiO}_{2}$ & 0.2 & 0.2 & 0.2 & 0.2 & 0.2 & 0.2 \\
\hline $\mathrm{Fe}_{2} \mathrm{O}_{3}$ & 9.8 & 9.6 & 9.7 & 9.4 & 9.6 & 9.0 \\
\hline $\mathrm{CaO}$ & 1.2 & 1.0 & 1.1 & 1.0 & 1.0 & 1.3 \\
\hline MgO & 12.4 & 12.8 & 12.6 & 12.7 & 13.0 & 12.4 \\
\hline $\mathrm{K}_{2} \mathrm{O}$ & 0.7 & 0.7 & 0.7 & 0.7 & 0.7 & 0.7 \\
\hline Total & 74.0 & 76.4 & 75.4 & 74.8 & 76.7 & 73.2 \\
\hline
\end{tabular}

SURFACE AREA

The surface area of the secondary mineralization sample has not been determined at this time. However, based on its mineralogy, it should yield a value between 600 and $800 \mathrm{~m}^{2} / \mathrm{g}$. 
APPENDIX C

SURFACE AREA MEASUREMENT WITH ETHYLENE GLYCOL 
APPENDIX C

SURFACE AREA MEASUREMENT WITH ETHYLENE GLYCOL

(Rai and Franklin 1978)

1. Prepare samples by saturating with $\mathrm{CaCl}_{2}$ : wash 15 grams of each sample with $200 \mathrm{ml}$ of $2 \mathrm{~N} \mathrm{CaCl}_{2}$, stir up, centrifuge and pour off supernatant, and repeat the washing. Then use distilled water to wash excess $\mathrm{CaCl}_{2}$ out of the samples. Stop washing with water when $\mathrm{AgNO}_{3}$ no longer precipitates with addition of the supernatant. Dry the samples either in an oven or by freeze drying.

2. Clean up aluminum moisture cans and place, without 1 ids on, in $105^{\circ} \mathrm{C}$ oven. After an hour remove cans from the oven and place in a desiccator with drierite. Wait until cooled, then weigh each can; minimize the adsorption of atmospheric water by the cans, before the cans are weighed. (Put each sample into cans.) Return cans plus samples (lids removed) to $105^{\circ} \mathrm{C}$ oven; leave for several hours.

3. At least six hours after samples were placed in the oven, make up $\mathrm{CaCl}_{2}$ - glycol solvate. Weigh out three-105 gram aliquots of 40 mesh $\mathrm{CaCl}_{2}$ each in a $400 \mathrm{ml}$ beaker. Place the beakers in a $210^{\circ} \mathrm{C}$ furnace. At the end of one hour reweigh the $\mathrm{CaCl}_{2}$ and return 100 grams of $\mathrm{CaCl}_{2}$ per beaker back into the furnace. Wait a few minutes before taking the $\mathrm{CaCl}_{2}$ out and mixing it with 20 grams of ethylene glycol. The heat of the $\mathrm{CaCl}_{2}$ plus vigorous mixing should result in a lumpfree, well-mixed solvate, which is important. Place each beaker in separate, sealed desiccators to cool.

4. While the $\mathrm{CaCl}_{2}-$ glycol solvates are cooling, remove the cans from the oven, placing lids on them before putting them into the desiccator with drierite. After the cans have cooled weigh each can; again, it is important to minimize the adsorption of atmospheric water by the cans and samples before being weighed. At the completion of weighing place the cans on a bench top and wet each sample with minimum amount of glycol ( $1 \mathrm{ml}$ or less) by applying dropwise over the surface of the samples. 
5. Take the beakers of $\mathrm{CaCl}_{2}-$ glycol solvate and uniformly cover the bottom of three different culture chambers. Set circular pieces of 1/4" mesh hardware cloth on top of the $\mathrm{CaCl}_{2}$ glycol solvate. Rubber stoppers keep the hardware cloth slightly above the $\mathrm{CaCl}_{2}$ glycol solvate. With the culture chambers ready, place one of each sample (lids off) in the culture chambers, this will make each chamber have four different samples. Before putting the culture chambers in separate desiccators, place the culture chamber lids on top of the chambers; don't seal them. Now that each culture chamber is in a desiccator hook up the vacuum pump to each desiccator for 45 minutes. After 16-24 hours, again apply the vaccum pump to each desiccator for 45 minutes.

6. When the samples have been in the desiccators for at least 48 hours, carefully weigh out each sample. After weighing, apply vacuum to each desiccator for 45 minutes. Wait at least 8 hours before reweighing. Repeat the weighing procedures until two successive weighings agree within a few tenths of a $\mathrm{mg}$.

7. Calculating the surface area:

- $A=W g /\left(W_{S} \times 0.00031\right)$

- $A=$ Surface area in $\mathrm{M}^{2} / \mathrm{g}$

- $W g=$ Weight (grams) of glycol retained by the sample

- $W s=$ Weight (grams) of sample.

0.00031 is Dyal-Hendricks value for grams of glycol required to form a monolayer on one $M^{2}$ of surface.

Note: Care should be taken in handling the aluminum moisture cans; any amount of dirt or prolonged contact with the atmosphere will affect the calculated surface area.

8. Equipment Used:

- 12 - aluminum boxes

- $3-25 \mathrm{~cm}$ desiccators

- 3 - culture chambers

- desiccator with drierite 
- vacuum pump

- $210^{\circ} \mathrm{C}$ furnace

\section{Chemicals}

- 40 mesh $\mathrm{CaCl}_{2}$

- $2 \mathrm{~N} \mathrm{CaCl}_{2}$

- Ethylene glycol

C. 3 
APPENDIX D

OUTLINE OF $150^{\circ} \mathrm{C}$ STATIC Kd EXPER IMENTS 
APPENDIX D

OUTLINE OF $150^{\circ} \mathrm{C}$ STATIC Kd EXPERIMENTS

COMMON PROCEDURE

1. Weigh out proper amount of solid material.

2. Place in pressure vessel without abrasion and generation of fines.

3. Measure proper volume of solution and place in the pressure vesse 1 pipette a $10 \mathrm{ml}$ aliquot of each traced solution used identify solution with a date because there may be more than one solution traced with the same radionuclides.

4. Cover vesse1.

5. With the gas exhaust valve through the cover open, gently purge the vesse 1 contents of oxygen with argon make sure that enough is used to displace the atmosphere above the bomb contents as well.

6. Close exhaust valve bring vessel to proper temperature and pressure.

7. Take samples of desired volume at proper times by first purging sample line with solution don't waste the solution by over-purging pipette desired volume into a marked scintillation vial immediately.

8. Where the circumstances permit, only the Ar pressure need be adjusted before resampling at the new pressure after the proper time interval.

9. After sampling is completed, cool the vessel and vent Ar pressure-discard solids and solution unless specifically asked to save one or the other.

10. Clean the vessel walls of quartz and other silicates if necessary the need for cleaning will have to be established by experimentation.

11. Repeat procedure on another experiment.

12. Keep good records of each experiment by filling out an autoclave data sheet for each of the experiments in each of the pressure vessels attach a xerox copy to each batch of samples taken for counting if 
possible identify each sample with a label that allows us to go to the notebook and find the experimental conditions such as radionuclides in the solution, run temperature and pressure, solids, etc. identify each pressure vessel with a number or letter and use solutions containing the same radionuclides in the same vessels each time contact us if there are any questions.

\section{SPECIFIC EXPERIMENTS}

1. Sr-Cs-Tc, Se-I, U, Pu; one group per vessel

a. blank solutions (no solids), $60 \mathrm{ml}$ each sample.

b. $150^{\circ} \mathrm{C}-4000 \mathrm{psi} \mathrm{Ar}$

c. $5 \mathrm{ml}$ samples at $24,48,96$ hours

d. total of 12 samples

2. Sr-Cs-TC, Se-I, U, Pu; Umtanum $20 \times 50$ mesh basalt

a. $250 \mathrm{ml}$ solution $/ 20 \mathrm{~g}$ basalt, no stirring

b. $150^{\circ} \mathrm{C}-4000 \mathrm{psi} \mathrm{Ar}$

c. $5 \mathrm{ml}$ samples every 3 days from startup to 30 days

d. total of 40 samples

3. Sr-Cs-Tc, Se-I, U, Pu; Flow E $20 \times 50$ mesh basalt

a. $200 \mathrm{ml}$ solution $/ 20 \mathrm{~g}$ basalt, no stirring

b. $150^{\circ} \mathrm{C}-4000$ psi $\mathrm{Ar}$

c. $10 \mathrm{ml}$ samples, 3 in succession each vessel at the optimal sampling time

d. total of 12 samples

4. Sr-Cs-Tc, Se-I, U, Pu; Pomona $20 \times 50$ mesh basalt

a. $200 \mathrm{ml}$ solution/20 g basalt, no stirring

b. $150^{\circ} \mathrm{C}, 4000$ psi $\mathrm{Ar}$

c. $10 \mathrm{~m} 1$ samples, 3 in succession each vessel optimal sampling time

d. total of 12 samples 
5. Sr-Cs-Tc, Se-I, U, Pu; Secondary Mineralization

a. $250 \mathrm{ml}$ solution/20 g clay, no stirring

b. $150^{\circ} \mathrm{C}, 4000 \mathrm{psi} \mathrm{Ar}$

c. $5 \mathrm{ml}$ samples every 3 days from startup to 30 days

d. total of 40 samples

6. Sr-Cs-Tc, Se-I, U, Pu; Umtanum $20 \times 50$ mesh basalt
a. $250 \mathrm{ml}$ solution $/ 20 \mathrm{~g}$ basalt, no stirring
b. $150^{\circ} \mathrm{C}, 1000$ psi pressure $\mathrm{Ar}$
c. $5 \mathrm{ml}$ samples every 3 days from startup to 30 days
d. total of 40 samples

7. Sr-Cs-Tc, Se-I, U, Pu; Umtanum $20 \times 50$ mesh basalt

a. $200 \mathrm{ml}$ solution $/ 20 \mathrm{~g}$ basalt, no stirring

b. $150^{\circ} \mathrm{C}, 2000 \mathrm{psi} \mathrm{Ar}$

c. $10 \mathrm{ml}$ samples, 3 in succession each vessel at optimal sampling time

d. total of 12 samples

8. Sr-Cs-TC, Se-I, U, Pu; Umtanum $20 \times 50$ mesh basalt

a. $200 \mathrm{ml}$ solution $/ 20 \mathrm{~g}$ basalt, no stirring

b. $150^{\circ} \mathrm{C}, 3000 \mathrm{psi} \mathrm{Ar}$

c. $10 \mathrm{ml}$ samples, 3 in succession each vessel at optimal sampling time

d. total of 12 samples

9. Sr-Cs-TC, Se-I, U, Pu; Umtanum $20 \times 50$ mesh basalt

a. $200 \mathrm{ml}$ solution $/ 20 \mathrm{~g}$ basalt, no stirring

b. $150^{\circ} \mathrm{C}, 4000 \mathrm{psi} \mathrm{Ar}$

c. $10 \mathrm{ml}$ samples, 3 in succession each vessel at optimal sampling time

d. total of 12 samples

10. Sr-Cs-TC, Se-I, U, Pu; Flow E $20 \times 50$ mesh basalt

a. $200 \mathrm{ml}$ solution $/ 20 \mathrm{~g}$ basalt, no stirring

b. $150^{\circ} \mathrm{C}, 1000 \mathrm{psi} \mathrm{Ar}$

c. $10 \mathrm{ml}$ samples, 3 in succession each vessel at optimal sampling time

d. total of 12 samples 
11. Sr-Cs-TC, Se-I, U, Pu; Flow E $20 \times 50$ mesh basalt
a. $200 \mathrm{ml}$ solution/20 g basalt, no stirring
b. $150^{\circ} \mathrm{C}, 2000 \mathrm{psi} \mathrm{Ar}$
c. $10 \mathrm{ml}$ samples, 3 in succession each vessel at optimal sampling time
d. total of 12 samples

12. Sr-Cs-Tc, Se-I, U, Pu; Flow E $20 \times 50$ mesh basalt
a. $200 \mathrm{ml}$ solution $/ 20 \mathrm{~g}$ basalt, no stirring
b. $150^{\circ} \mathrm{C}, 3000 \mathrm{psi} \mathrm{Ar}$
c. $10 \mathrm{ml}$ samples, 3 in succession each vessel at optimal sampling time
d. total of 12 samples

13. Sr-Cs-Tc, Se-I, U, Pu; Flow E $20 \times 50$ mesh basalt
a. $200 \mathrm{ml}$ solution/20 g basalt, no stirring
b. $150^{\circ} \mathrm{C}, 4000 \mathrm{psi} \mathrm{Ar}$
c. $10 \mathrm{ml}$ samples, 3 in succession each vessel at optimal sampling time
d. total of 12 samples

14. Sr-Cs-TC, Se-I, U, Pu; Secondary Mineralization
a. $200 \mathrm{ml}$ solution/20 g clay, no stirring
b. $150^{\circ} \mathrm{C}, 1000$ psi Ar
c. $5 \mathrm{ml}$ samples, 3 in succession each vessel at optimal sampling time
d. total of 40 samples

15. Sr-Cs-Tc, Se-I, U, Pu; Secondary Mineralization
a. $200 \mathrm{ml}$ solution/20 g clay, no stirring
b. $150^{\circ} \mathrm{C}, 2000 \mathrm{psi} \mathrm{Ar}$
c. $5 \mathrm{ml}$ samples, 3 in succession each vessel at optimal sampling time
d. total of 12 samples

16. Sr-Cs-Tc, Se-I, U, Pu; Secondary Mineralization
a. $200 \mathrm{ml}$ solution/20 g clay, no stirring
b. $150^{\circ} \mathrm{C}, 3000 \mathrm{psi} \mathrm{Ar}$
c. $5 \mathrm{ml}$ samples, 3 in succession each vessel at optimal sampling time
d. total of 12 samples 
17. Sr-Cs-TC, Se-I, U, Pu; Secondary Mineralization

a. $200 \mathrm{ml}$ solution/20 g clay, no stirring

b. $150^{\circ} \mathrm{C}, 4000 \mathrm{psi} \mathrm{Ar}$

c. $5 \mathrm{ml}$ samples, 3 in succession each vessel at optimal sampling time

d. total of 12 samples

Clean and Decontaminate All Four Vessels

Repeat (1) with $\mathrm{Ra}, \mathrm{Np}, \mathrm{Am}$

18. Ra, Np, Am; Umtanum $20 \times 50$ mesh basalt

a. $250 \mathrm{ml}$ solution/20 g clay, no stirring

b. $150^{\circ} \mathrm{C}, 4000 \mathrm{psi} \mathrm{Ar}$

c. $5 \mathrm{ml}$ samples 3 days from startup to 30 days

d. total of 40 samples

19. Ra, Np, Am; Flow E $20 \times 50$ mesh basalt

a. $200 \mathrm{ml}$ solution/20 g clay, no stirring

b. $150^{\circ} \mathrm{C}, 4000 \mathrm{psi} \mathrm{Ar}$

c. $10 \mathrm{ml}$ samples, 3 in succession each vessel at optimal sampling time

d. total of 9 samples

20. Ra, Np, Am; Pomona $20 \times 50$ mesh basalt

a. $200 \mathrm{ml}$ solution/20 g clay, no stirring

b. $150^{\circ} \mathrm{C}, 4000 \mathrm{psi} \mathrm{Ar}$

c. $10 \mathrm{ml}$ samples, 3 in succession each vessel at optimal sampling time

d. total of 9 samples

21. Ra, Np, Am; Secondary Mineralization

a. $250 \mathrm{ml}$ solution/20 g clay, no stirring

b. $150^{\circ} \mathrm{C}, 4000$ psi $\mathrm{Ar}$

c. $5 \mathrm{ml}$ samples every 3 days from startup to 30 days

d. total of 30 samples 
22. Ra, Np, Am; Umtanum $20 \times 50$ mesh basalt
a. $250 \mathrm{~m} 1$ solution/20 g clay, no stirring
b. $150^{\circ} \mathrm{C}, 1000 \mathrm{psi} \mathrm{Ar}$
c. $5 \mathrm{~m} 1$ samples every 3 days from startup to 30 days
d. total of 30 samples

23. Ra, Np, Am; Umtanum $20 \times 50$ mesh basalt
a. $200 \mathrm{ml}$ solution/20 g clay, no stirring
b. $150^{\circ} \mathrm{C}, 2000$ psi $\mathrm{Ar}$
c. $10 \mathrm{ml}$ samples, 3 in succession each vessel at optimal sample time d. total of 9 samples

24. Ra, Np, Am; Umtanum $20 \times 50$ mesh basalt
a. $200 \mathrm{ml}$ solution $/ 20 \mathrm{~g}$ clay, no stirring
b. $150^{\circ} \mathrm{C}, 3000$ psi $\mathrm{Ar}$
c. $10 \mathrm{ml}$ samples, 3 in succession each vessel at optimal sample time
d. total of 9 samples

25. Ra, Np, Am; Umtanum $20 \times 50$ mesh basalt
a. $200 \mathrm{ml}$ solution/20 g clay, no stirring
b. $150^{\circ} \mathrm{C}, 4000$ psi $\mathrm{Ar}$
c. $10 \mathrm{ml}$ samples, 3 in succession each vessel at optimal sample time
d. total of 9 samples

26. Ra, Np, Am; Flow E $20 \times 50$ mesh basalt
a. $200 \mathrm{ml}$ solution/20 g clay, no stirring
b. $150^{\circ} \mathrm{C}, 1000$ psi $\mathrm{Ar}$
c. $10 \mathrm{ml}$ samples, 3 in succession each vessel at optimal sample time
d. total of 9 samples

27. Ra, Np, Am; Flow E $20 \times 50$ mesh basalt
a. $200 \mathrm{ml}$ solution/20 g clay, no stirring
b. $150^{\circ} \mathrm{C}, 2000$ psi $\mathrm{Ar}$
c. $10 \mathrm{ml}$ samples, 3 in succession each vessel at optimal sample time
d. total of 9 samples 
28. Ra, Np, Am; Flow E $20 \times 50$ mesh basalt
a. $200 \mathrm{ml}$ solution/20 g clay, no stirring
b. $150^{\circ} \mathrm{C}, 3000$ psi $\mathrm{Ar}$
c. $10 \mathrm{ml}$ samples, 3 in succession each vesse 1 at optimal sample time
d. total of 9 samples

29. Ra, Np, Am; Flow E $20 \times 50$ mesh basalt
a. $200 \mathrm{ml}$ solution $/ 20 \mathrm{~g}$ clay, no stirring
b. $150^{\circ} \mathrm{C}, 4000$ psi $\mathrm{Ar}$
c. $10 \mathrm{ml}$ samples, 3 in succession each vesse 1 at optimal sample time
d. total of 9 samples

30. Ra, Np, Am; Pomona $20 \times 50$ mesh basalt
a. $200 \mathrm{ml}$ solution/20 g clay, no stirring
b. $150^{\circ} \mathrm{C}, 1000 \mathrm{psi} \mathrm{Ar}$
c. $10 \mathrm{ml}$ samples, 3 in succession each vessel at optimal sample time
d. total of 9 samples

31. Ra, Np, Am; Pomona $20 \times 50$ mesh basalt
a. $200 \mathrm{ml}$ solution/20 g clay, no stirring
b. $150^{\circ} \mathrm{C}, 2000 \mathrm{psi} \mathrm{Ar}$
c. $10 \mathrm{ml}$ samples, 3 in succession each vessel at optimal sample time
d. total of 9 samples

32. Ra, Np, Am; Pomona $20 \times 50$ mesh basalt
a. $200 \mathrm{ml}$ solution $/ 20 \mathrm{~g}$ clay, no stirring
b. $150^{\circ} \mathrm{C}, 3000 \mathrm{psi} \mathrm{Ar}$
c. $10 \mathrm{ml}$ samples, 3 in succession each vesse 1 at optimal sample time
d. total of 9 samples

33. Ra, Np, Am; Pomona $20 \times 50$ mesh basalt
a. $200 \mathrm{ml}$ solution/20 g clay, no stirring
b. $150^{\circ} \mathrm{C}, 4000 \mathrm{psi} \mathrm{Ar}$
c. $10 \mathrm{ml}$ samples, 3 in succession each vessel at optimal sample time
d. total of 9 samples


34. Ra, Np, Am; Secondary Mineralization
a. $250 \mathrm{ml}$ solution/20 g clay, no stirring
b. $150^{\circ} \mathrm{C}, 1000 \mathrm{psi} \mathrm{Ar}$
c. $5 \mathrm{ml}$ samples every 3 days from startup to 30 days
d. total of 30 samples

35. Ra, Np, Am; Secondary Mineralization
a. $200 \mathrm{ml}$ solution/20 g clay, no stirring
b. $150^{\circ} \mathrm{C}, 2000$ psi $\mathrm{Ar}$
c. $10 \mathrm{ml}$ samples, 3 in succession each vessel at optimal sample time
d. total of 9 samples

36. Ra, Np, Am; Secondary Mineralization
a. $200 \mathrm{ml}$ solution/20 g clay, no stirring
b. $150^{\circ} \mathrm{C}, 3000$ psi $\mathrm{Ar}$
c. $10 \mathrm{ml}$ samples, 3 in succession each vessel at optimal sample time
d. total of 9 samples

37. Ra, Np, Am; Secondary Mineralization
a. $200 \mathrm{ml}$ solution/20 g clay, no stirring
b. $150^{\circ} \mathrm{C}, 4000$ psi $\mathrm{Ar}$
c. $10 \mathrm{ml}$ samples, 3 in succession each vessel at optimal sample time
d. total of 9 samples 
APPENDIX E

OUTLINE OF $300^{\circ} \mathrm{C}$ STATIC Kd EXPER IMENTS 


\section{OUTLINE OF $300^{\circ} \mathrm{C}$ STATIC Kd EXPERIMENTS}

\section{COMMON PROCEDURE}

1. Weigh out proper amount of solid material.

2. Place in pressure vessel without abrasion and generation of fines.

3. Measure proper volume of solution and place in the pressure vessel pipette a $10 \mathrm{ml}$ aliquot of each traced solution used - identify solution with a date because there may be more than one solution traced with the same radionuclides.

4. Cover vessel.

5. With the gas exhaust valve through the cover open, gently purge the vessel contents of oxygen with argon - make sure that enough is used to displace the atmosphere above the bomb contents as well.

6. Close exhaust valve - bring vessel to proper temperature and pressure.

7. Take samples of desired volume at proper times by first purging sample line with solution - don't waste the solution by over-purging - pipette desired volume into a marked scintillation vial immediately. Secondary mineralization (clay) may not be removed by the $10 \mathrm{um}$ line filter. Check sample for solids before pipetting.

8. Where the circumstances permit, only the Ar pressure need be adjusted before resampling at the new pressure after the proper time interval.

9. After sampling is completed, cool the vessel and vent Ar pressure-discard solids and solution unless specifically asked to save one or the other.

10. Clean the vessel walls of quartz and other silicates if necessary - the need for cleaning will have to be established by experimentation.

11. Repeat procedure on another experiment. 
12. Keep good records of each experiment by filling out an autoclave data sheet for each of the experiments in each of the pressure vessels attach a xerox copy to each batch of samples taken for counting if possible - identify each sample with a label that allows us to go to the notebook and find the experimental conditions such as radionuclides in the solution, run temperature and pressure, solids, etc. - identify each pressure vessel with a number or letter and use solutions containing the same radionuclides in the same vessels each time - contact us if there are any questions.

13. Radionuclide adsorption should be less on titanium and Zircaloy vessels than on the $100 \mathrm{~K}$ area Inconel vessels. If not, these two vessels also may need to be Teflon-lined.

\section{SPECIFIC EXPERIMENTS}

1. Sr-Cs, Tc; one group per vessel

a. blank solutions (no solids), $100 \mathrm{ml}$ each

b. $300^{\circ} \mathrm{C}-4000 \mathrm{psi} \mathrm{Ar}$

c. 3 successive $5 \mathrm{ml}$ samples at $24,48,96$ hours

d. total of 9 samples each for $\mathrm{Sr}-\mathrm{Cs}$ and $\mathrm{TC}$

2. Sr-Cs, Tc; Umtanum $20 \times 50$ mesh basalt

a. $250 \mathrm{ml}$ solution $/ 20 \mathrm{~g}$ basalt, no stirring

b. $300^{\circ} \mathrm{C}-4000 \mathrm{psi} \mathrm{Ar}$

c. 3 successive $5 \mathrm{ml}$ samples every 3 days from startup to 30 days

d. total of 30 samples each for $\mathrm{Sr}-\mathrm{Cs}$ and $\mathrm{TC}$

3. Sr-Cs, Tc; Umtanum $20 \times 50$ mesh basalt

a. $500 \mathrm{ml}$ solution/10 g basalt, no stirring

b. $300^{\circ} \mathrm{C}-4000 \mathrm{psi} \mathrm{Ar}$

c. 3 successive $5 \mathrm{ml}$ samples each vessel at the optimal sampling time

d. total of 3 samples each for Sr-Cs and TC 
4. Sr-Cs, TC; Pomona $20 \times 50$ mesh basalt

a. $250 \mathrm{ml}$ solution $/ 20 \mathrm{~g}$ basalt, no stirring

b. $300^{\circ} \mathrm{C}-4000 \mathrm{psi} \mathrm{Ar}$

c. 3 successive $5 \mathrm{ml}$ samples each vessel at the optimal sampling time

d. total of 3 samples each for $\mathrm{Sr}-\mathrm{Cs}$ and TC

5. Sr-Cs, TC; Flow E $20 \times 50$ mesh basalt

a. $250 \mathrm{ml}$ solution $/ 20 \mathrm{~g}$ basalt, no stirring

b. $300^{\circ} \mathrm{C}-4000 \mathrm{psi} \mathrm{Ar}$

c. 3 successive $5 \mathrm{ml}$ samples each vessel at the optimal sampling time

d. total of 3 samples each for $S r-C s$ and Tc

6. Sr-Cs, Tc; Secondary Mineralization

a. $250 \mathrm{ml}$ solution $/ 10 \mathrm{~g}$ basalt, no stirring

b. $300^{\circ} \mathrm{C}-4000 \mathrm{psi} \mathrm{Ar}$

c. 3 successive $5 \mathrm{ml}$ samples every 3 days from startup to 30 days

d. total of 30 samples each for Sr-Cs and TC

\section{CLEAN AND DECONTAMINATE BOTH VESSELS}

7. U, Ra; one per vessel

a. blank solutions (no solids), $100 \mathrm{ml}$ each

b. $300^{\circ} \mathrm{C}-4000$ psi $\mathrm{Ar}$

c. 3 successive $5 \mathrm{ml}$ samples at $24,48,96$ hours

d. total of 9 samples each for $U$ and $R a$

8. U, Ra; Umtanum $20 \times 50$ mesh basalt

a. $250 \mathrm{~m} 1$ solution/20 $\mathrm{g}$ basalt, no stirring

b. $300^{\circ} \mathrm{C}-3000$ psi $\mathrm{Ar}$

c. 3 successive $5 \mathrm{ml}$ samples every day from startup to 30 days

d. total of 30 samples each for $U$ and Ra

9. U, Ra; Pomona $20 \times 50$ mesh basalt

a. $250 \mathrm{~m} 1$ solution $/ 20 \mathrm{~g}$ basalt, no stirring

b. $300^{\circ} \mathrm{C}-4000 \mathrm{psi} \mathrm{Ar}$ 
c. 3 successive $5 \mathrm{ml}$ samples each vessel at the optimal sampling time

d. total of 3 samples each for $U$ and $R a$

10. U, Ra; Flow E $20 \times 50$ mesh basalt

a. $250 \mathrm{ml}$ solution/20 g basalt, no stirring

b. $300^{\circ} \mathrm{C}-4000$ psi $\mathrm{Ar}$

c. 3 successive $5 \mathrm{ml}$ samples each vessel at the optimal sampling time

d. total of 3 samples each for $U$ and $R a$

11. U, Ra; Secondary Mineralization

a. $250 \mathrm{ml}$ solution/10 g basalt, no stirring

b. $300^{\circ} \mathrm{C}-4000 \mathrm{psi} \mathrm{Ar}$

c. 3 successive $5 \mathrm{ml}$ samples every day from startup to 30 days

d. total of 3 samples each for $U$ and $R a$

\section{CLEAN AND DECONTAMINATE BOTH VESSELS}

12. Se-I, Np; one group per vessel

a. blank solutions (no solids), $100 \mathrm{ml}$ each

b. $300^{\circ} \mathrm{C}-4000$ psi

c. 3 successive $5 \mathrm{ml}$ samples at $24,48,96$ hours

d. total of 9 smples each for Se-I, Np

13. Se-I, Np; Untamum $20 \times 50$ mesh basalt

a. $250 \mathrm{ml}$ solution/20 g basalt, no stirring

b. $300^{\circ} \mathrm{C}-4000 \mathrm{psi} \mathrm{Ar}$

c. 3 successive $5 \mathrm{ml}$ samples every 3 days from startup to 30 days

d. total of 30 samples each for Se-I and $\mathrm{Np}$

14. Se-I, Np; Pomona $20 \times 50$ mesh basalt

a. $250 \mathrm{ml}$ solution $/ 20 \mathrm{~g}$ basalt, no stirring

b. $300^{\circ} \mathrm{C}-4000$ psi $\mathrm{Ar}$

c. 3 successive $5 \mathrm{ml}$ samples each vessel at the optimal sampling time

d. total of 3 samples each for Se-I and $\mathrm{Np}$ 
15. Se-I, Np; Flow E $20 \times 50$ mesh basalt
a. $250 \mathrm{ml}$ solution $/ 20 \mathrm{~g}$ basalt, no stirring
b. $300^{\circ} \mathrm{C}-4000 \mathrm{psi} \mathrm{Ar}$
c. 3 successive $5 \mathrm{ml}$ samples each vessel at the optimal sampling time
d. total of 3 samples each for Se-I and Np

16. Se-I, Np; Secondary Mineralization
a. $250 \mathrm{ml}$ solution $/ 10 \mathrm{~g}$ basalt, no stirring
b. $300^{\circ} \mathrm{C}-4000$ psi $\mathrm{Ar}$
c. 3 successive $5 \mathrm{ml}$ samples every 3 days from startup to 30 days
d. total of 30 samples each for Se-I and $\mathrm{Np}$

\section{CLEAN AND DECONTAMINATE BOTH VESSELS}

17. Am, Pu; one per vesse 1
a. blank solutions (no solids), $100 \mathrm{ml}$ each
b. $300^{\circ} \mathrm{C}-4000$ psi $\mathrm{Ar}$
c. 3 successive $5 \mathrm{ml}$ samples at $24,48,96$ hours
d. total of 9 smples each for Am and Pu

18. Am, Pu; Umtanum $20 \times 50$ mesh basalt
a. $250 \mathrm{ml}$ solution/20 g basalt, no stirring
b. $300^{\circ} \mathrm{C}-4000$ psi $\mathrm{Ar}$
c. 3 successive $5 \mathrm{ml}$ samples every 3 days from startup to 30 days
d. total of 30 samples each for Am and Pu

19. Am, Pu; Pomona $20 \times 50$ mesh basalt
a. $250 \mathrm{ml}$ solution $/ 20 \mathrm{~g}$ basalt, no stirring
b. $300^{\circ} \mathrm{C}-4000 \mathrm{psi} \mathrm{Ar}$
c. 3 successive $5 \mathrm{ml}$ samples each vessel at the optimal sampling time
d. total of 3 samples each for Am and Pu

20. Am, Pu; Flow E $20 \times 50$ mesh basalt
a. $250 \mathrm{ml}$ solution $/ 20 \mathrm{~g}$ basalt, no stirring
b. $300^{\circ} \mathrm{C}-4000 \mathrm{psi} \mathrm{Ar}$ 
c. 3 successive $5 \mathrm{~m} 7$ samples each vessel at the optimal sampling time

d. total of 3 samples each for Am and Pu

21. Am, Pu; Secondary Mineralization
a. $250 \mathrm{ml}$ solution $/ 10 \mathrm{~g}$ basalt, no stirring
b. $300^{\circ} \mathrm{C}-4000$ psi $\mathrm{Ar}$
c. 3 successive $5 \mathrm{~m} 1$ samples every 3 days from startup to 30 days
d. total of 30 samples each for Am and Pu 
APPENDIX $F$ EFFECTS OF WEATHERING ON SURFACES OF UMTANUM BASALT 
APPENDIX $F$

\section{EFFECTS OF WEATHERING ON SURFACES OF UMTANUM BASALT}

Figure F.1 shows a 50 times magnification of a weathered zone perpendicular to a fissure in the surface-gathered Umtanum basalt. The weathered zone is compared to a similar magnification of hydrothermally treated $\left(300^{\circ} \mathrm{C}\right.$, 13.8 MPa Ar, 21 days equilibration, $20 \mathrm{~g}$ Umtanum 20- to 50 -mesh basalt/600 ml synthetic groundwater of Table 2) Umtanum basalt in Figure F.2. The results are very similar, with initial alteration of the glass phase in both cases.

Scanning electron micrograph (SEM) photos comparing the weathered and unweathered basalt areas are given in Figures F.3 through F.6. The two white fragments on the 500X unweathered photo are probably polishing agent and not a part of the basalt. The difference in the state of the glassy groundmass between the weathered and unweathered portions of the basalt are striking. In the weathered portion, parts of the glass are dissolved, leaving considerable porosity, and resulting in the synthesis of other, more stable mineral phases, such as the smectites.

The glass phase is high in silica and potash. Electron maps of silicon and potassium are shown in the third glossy photo at a magnification of 100 across the weathered zone-unweathered zone contact. Note that the weathered zone is lower in silicon and potassium indicating that the glass phase is altering by weathering type reactions even in this relatively low rainfall area. The glass phase of the basalt very likely controls the groundwater composition that is in chemical equilibrium with it. Variations in glass composition could be reflected in some cases by radionuclide Kd variations. 


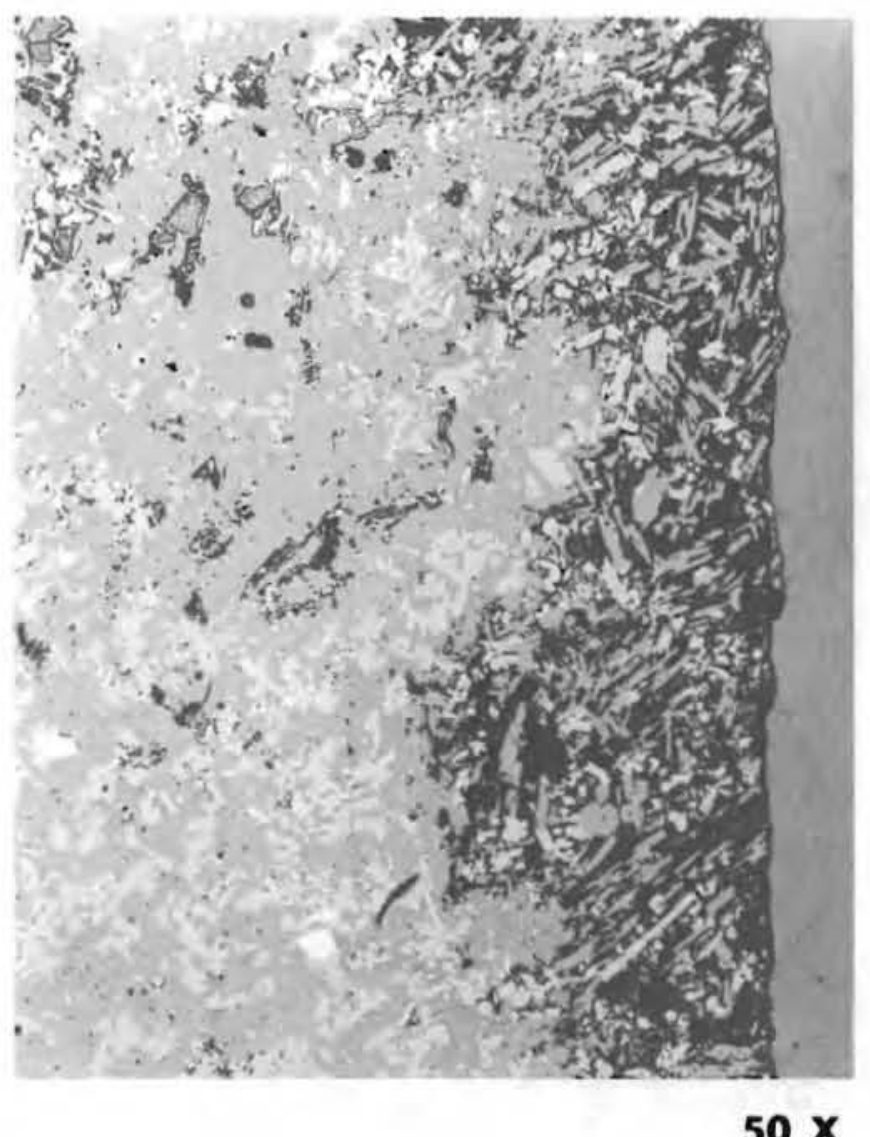

FIGURE F.1. Weathered Basalt Section

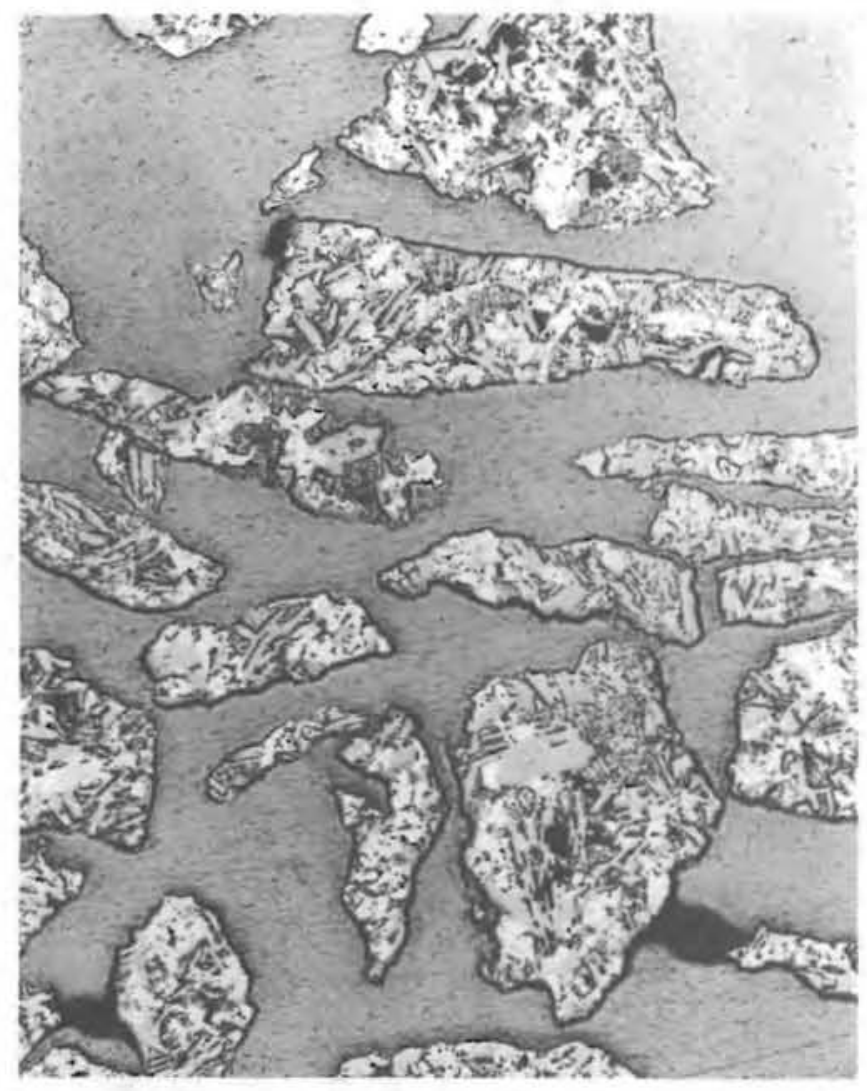

$50 \times$

FIGURE F.2. Hydrothermally Treated Basalt Section 


\section{$500 x$}

$i_{\omega}^{\pi}$

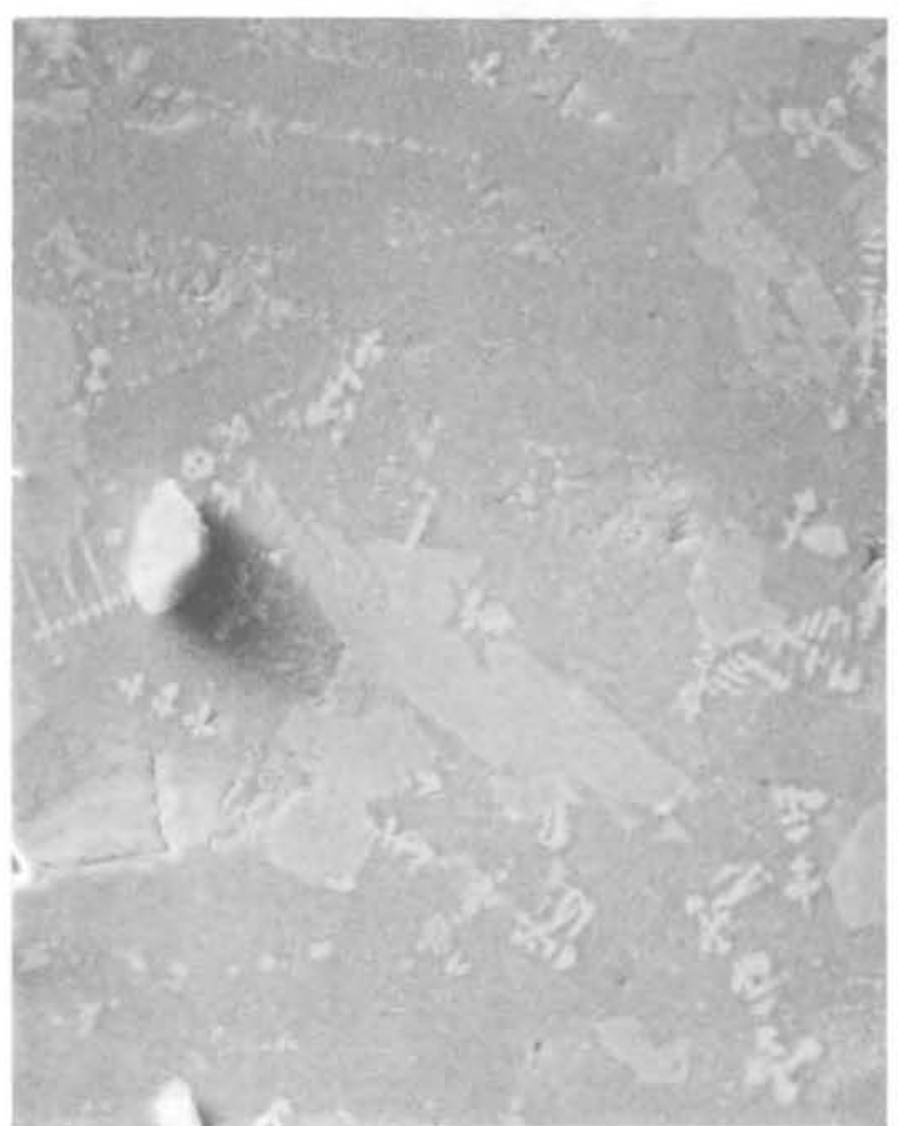

FIGURE F.3. Unweathered Basalt Section

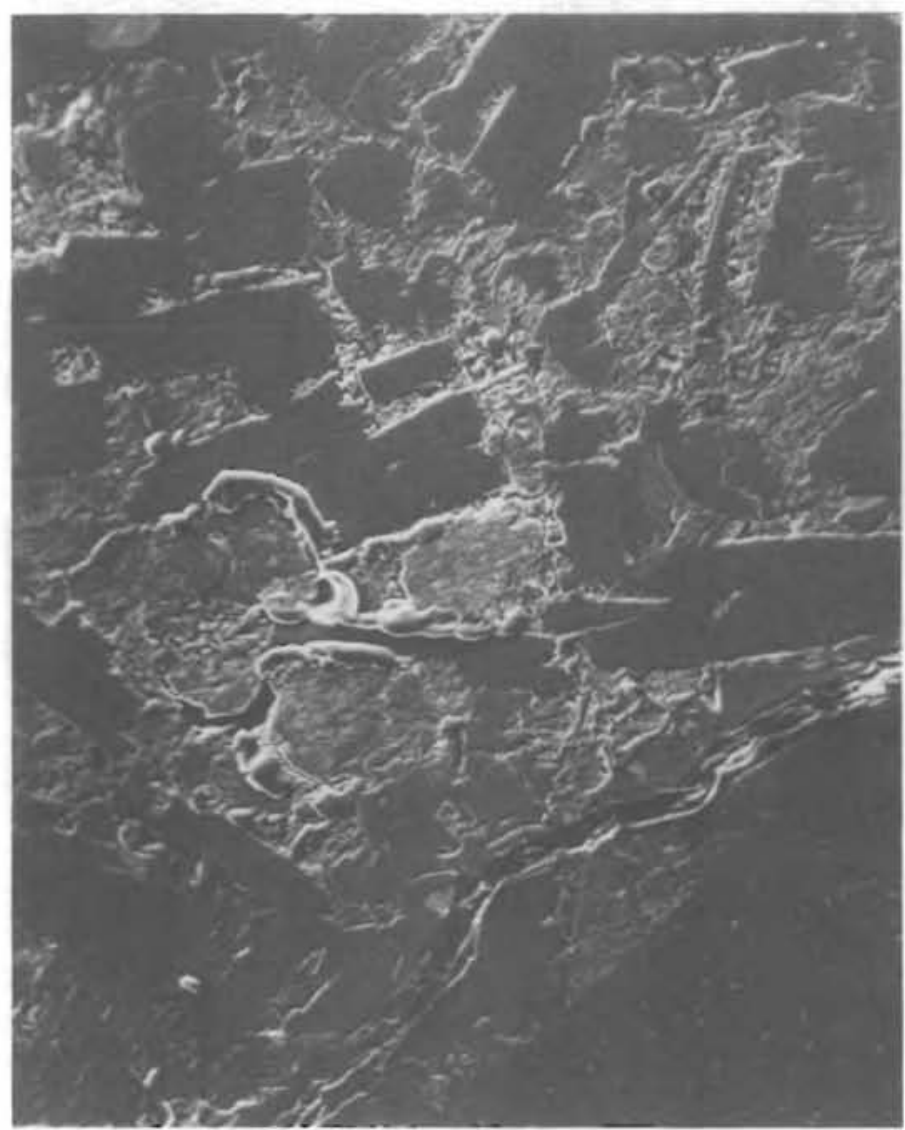

FIGURE F.4. Weathered Basalt Section 


\section{$2000 x$}

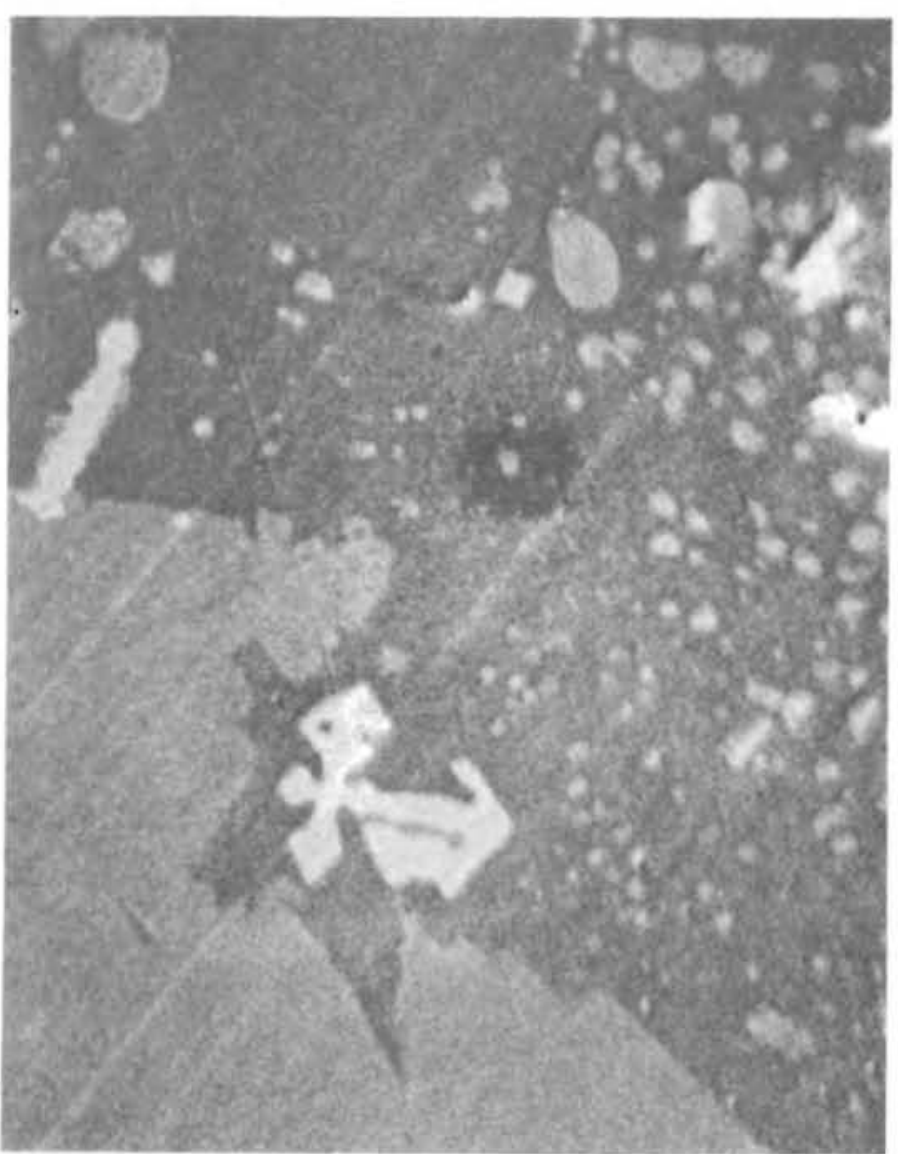

FIGURE F.5. Unweathered Basalt Section

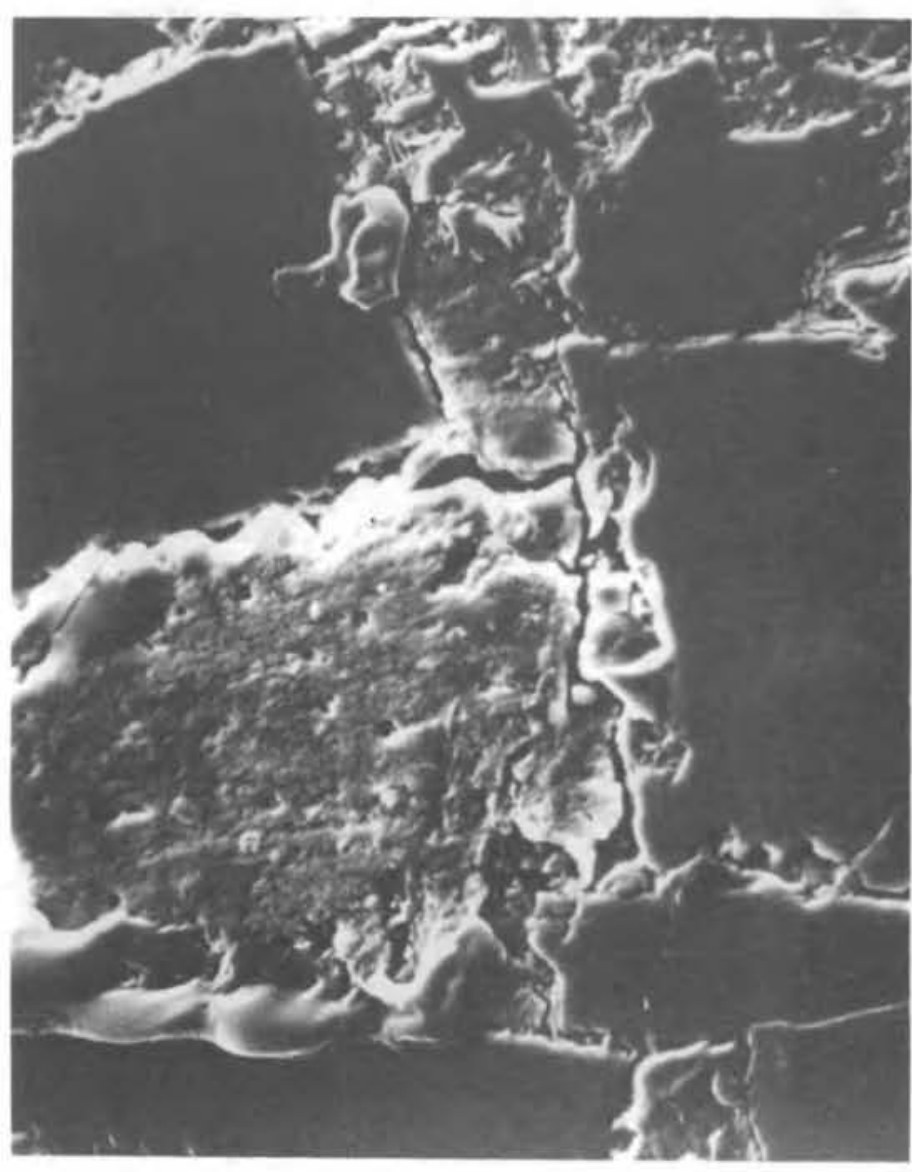

FIGURE F.6. Weathered Basalt Section 


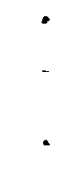




\section{DISTRIBUTION}

No. of

Copies

OFFSITE

A. A. Churm

DOE Patent office

$9800 \mathrm{~S}$. Cass Avenue

Argonne, IL 60439

27 DOE Technical Information Center

J. F. T. Agapito

2449 Bella Pago Drive

Grand Junction, CO 81501

Central Washington University

Department of Geology

Ellensburg, WA 98926

J. W. Corwine

U.S.Dept. of Interior

Bureau of Mines

E315 Montgomery Avenue

Spokane, WA 99206

J. G. Bond

Geoscience Research Consultants

641 N. Hayges

Moscow, ID 83843

M. M. Miller

Idaho Bureau of Mines and Geology

University of Idaho

Morrell Hall, Room 332

Moscow, ID 83843

J. D. Beaulieu

Oregon State Dept. of Geology and Mineral Industries

1069 State Office Bldg.

Portland, OR 97201
No. of

Copies

Oregon State University

Dept. of Geology

Corvallis, OR 97331

I. Remson

Dept. of Applied Earth Sciences

Stanford University

Stanford, CA 94305

F. L. Parker

Vanderbilt University

Nashville, TN 37235

D. Newmann

U.S. Bureau of Reclamation

Ephrata, WA 98823

J. 0. Neff

U.S. Dept. of Energy

Columbus Program office

$505 \mathrm{King}$ Avenue

Columbus, $\mathrm{OH} 43201$

M. W. Frei

U.S. Department of Energy

10 Massachusetts Avenue N.W.

Washington, DC 20545

D. L. Vieth

U.S. Department of Energy

20 Massachusetts Ave. N.W.

Washington, DC 20545

C. Collier

USGS

1201 Pacific Avenue

Suite 600

Tacoma, WA 98402 
No. of

Copies

University of Idaho

Library

Moscow, ID 83843

University of Washington

Library

Seattle, WA 98195

D. D. Tillson

Washington Public Power

Supply System

3000 George Washington Way

Richland, WA 99352

P. Grimstad

Washington State Department

of Ecology

Olympia, WA 98504

V. E. Livington

Washington State Department of Natural Resources

01 ympia, WA 98501

Washington State University

Department of Geology

Pullman, WA 99164

A. C. Waters

308 Moore St.

Santa Cruz, CA 95060

H. C. Wieseneck

Atomics International

P. 0. Box 309

Canoga Park, CA 91304

Western Washington University

Dept. of Geology

Bellingham, WA 98225
No. of

Copies

ONSITE

37 Rockwell Hanford Operations

H. Babad

D. J. Brown

T. A. Curran (5)

R. A. Deju (2)

R. C. Edwards

R. E. Gephart

R. E. Isaacson

C. W. Myers

W. H. Price (5)

Basalt Waste Isolation

Program Library (15)

Document Control (4)

3 DOE Richland Operations Office

R. B. Goranson

H. E. Ransom

D. J. Squires

16 Pacific Northwest Laboratory

L. L. Ames (2)

J. R. Raymopnd

R. J. Serne

Technical Information (5)

Publishing Coordination (2)

Water and Land Resources

Department Library (5) 